\title{
Review on Energy and Fire Performance of Water Wall Systems as a Green Building Façade
}

\author{
Uthpala Rathnayake ${ }^{1}$, Denvid Lau ${ }^{1,2}$ (D) and Cheuk Lun Chow ${ }^{1, *}$ \\ 1 Department of Architecture and Civil Engineering, City University of Hong Kong, Hong Kong, China; \\ rrathnaya2-c@my.cityu.edu.hk (U.R.); denvid.lau@cityu.edu.hk (D.L.) \\ 2 Department of Civil and Environmental Engineering, Massachusetts Institute of Technology, Cambridge, \\ MA 02139, USA \\ * Correspondence: cheuchow@cityu.edu.hk
}

Received: 9 September 2020; Accepted: 13 October 2020; Published: 21 October 2020

\begin{abstract}
Glass façades are widely utilized in green buildings. Ensuring fire safety while reducing the energy need without compromising occupants' comfort is a challenge in the modern-day green buildings with glass façades. One way of achieving both aspects is to construct a water wall system as a building façade. A water wall system has a water layer between two glass panes and can be considered as a glass façade system. The focus of this review, which builds on the published studies, is how water wall systems can help ensure fire safety and reduce energy demand in green buildings. The water layer within two glass panes of the water wall system store the solar radiation heat throughout the daytime, reducing the amount of heat transferred through the building facade. The reduced heat transfer effects lessen the need for air conditioning to sustain the thermal comfort of the building occupants. The stored energy is released during the nighttime. The transparency of the water wall system also allows daylight to enter the building, thus reducing artificial lighting needs. Furthermore, the water layer acts as a fire safety mechanism in case of a fire. However, the water wall systems are not much utilized in the modern-day green buildings due to their unpopularity and the unavailability of design guidelines. On the basis of the findings of the literature review, stakeholders and the public are encouraged to adopt water wall systems in green building projects as an energy-efficient strategy and a fire safety mechanism.
\end{abstract}

Keywords: green building; glass façade; water wall; energy; fire safety

\section{Introduction}

The façade, which is the skin of the building, separates the interior space from the external environment. There is an urgent need to design and construct the building façades to be more energy-efficient, as an approximate $20-60 \%$ of building heating and cooling energy is influenced by the façade design and construction [1,2]. Therefore, the construction industry is moving towards green façade constructions, putting much focus on the energy-efficiency of the façade [3], and glass is widely used in the façade constructions [4]. Apart from energy efficiency, green building façades have a less negative impact on the environment and provide a better indoor environment that might contribute to wellbeing, productivity, and performance of the occupants. For this purpose, a green building façade should satisfy several requirements, such as facilitating outside views, withstanding wind loads, air and water penetrations, sustaining its dead load weight, allowing daylight to the building interior, obstructing undesirable solar heat gain, blocking outside noise and reducing temperature fluctuations, and ultimately boosting the overall building performance [5-8]. The materials used in the façade construction have a considerable effect in performing these green façade functions [9,10]. Glass is considered an appropriate material to be used in green building façades. In consideration of the 
complete building life cycle, the negative environmental impact of glass is minimal [11]. The primary constituent of glass is sand, which is a non-polluting material, glass manufacturing processes are considered as energy-efficient as they require a low amount of water, and waste generation is less and recyclable at the end of the life cycle [12,13]. The glass façades are transparent, allowing outside views and substantially reducing the energy use for artificial lighting as they allow sufficient daylight to enter the building during the daytime. However, if not correctly designed, solar gain through heat transmittance of glass façades can be as high as $85 \%$ of the incident radiation [14]. This transferred heat raises the air temperature inside the building, creating a high demand for air conditioners to keep up the occupants' thermal comfort. It increases the building energy consumption, as air conditioners are high energy consumers and would result in high energy bills [15]. Furthermore, using more energy means more carbon emissions [16], and thereby is contrary to the primary aim of using a green building. Having a system to prevent heat transmittance through the façade lowers the building energy demand [17], which results in less carbon emissions [18,19]. Therefore, careful consideration is needed in designing the glass façades to get the delicate balance of energy over the building envelope together with adequate daylight to reduce the artificial lighting [2,20-22].

Moreover, careful consideration of the fire safety qualities of glazed façades is essential in designing, as a glazed façade can be the most critical element of building fire spread if it is not designed with adequate fire resistance [23]. Façades or windows made of glass are the most fragile and weakest elements of buildings $[24,25]$ owing to the comparatively poor tensile strength and the brittle behavior of glass relative to other building materials [26,27]. In a fire situation, the breakage and fallout of glass would create a new vent for fresh air entrainment and fire spread, which may significantly accelerate fire development [20,26-31]. Falling parts of façades onto the ground might create secondary fires, which is another problem associated with glass façades. Furthermore, in the absence of adequate fire protection systems, fire would escalate carbon emissions by $30-40 \mathrm{~kg}$ of $\mathrm{CO}_{2} / \mathrm{m}^{2}$ over the life cycle of a standard building [32], and if exposed to extensive fire hazards, it can add up to an extra $14 \%$. The effort to improve energy efficiency without considering fire safety has the potential to expand the fire risk by a factor of three [33]. Therefore, the integration of fire safety features is vital for a building to be considered green. Water wall systems (WWS) allow the integration of both of these aspects, making it a solution that is well suited for the green building façades.

WWS are traditionally considered as an excellent design to maintain the occupants' thermal comfort while reducing the building's energy use [34-43]. WWS store the thermal energy during the day and release it during the night, reducing the energy need for summer cooling and winter heating. Furthermore, it reduces the energy consumption for artificial lighting in the daytime, as a portion of the solar energy enters the building through the WWS [35]. These advantages of WWS have been discussed by a significant number of authors in the literature. These studies have emphasized that the correct design of the WWS depends on a variety of comprehensive construction, building, and weather details. These include orientation of the facade glass transparency and thermal resistance, space thermal balance, façade thermal capacity, the openness of the interior, and local climate. This very complex multi-parameter feature makes it very difficult to develop simple design rules based on mathematical models. Besides, the experimental results are strictly related to a unique morphology, thus generalizing the results is difficult. Advanced simulation studies are needed for this reason.

Apart from energy-saving, WWS offer an additional benefit for fire safety, as there is always a water layer between the two glass panes. The water layer absorbs the heat from interior fire or exterior fire. As water has a high specific heat capacity of $4.2 \mathrm{~kJ} / \mathrm{K}$, water absorbs a large amount of energy from the fire before the glass temperature escalates to its breakage temperature. The glass panes heat up more slowly with the water layer and delay the glass breakage. With this effect, the WWS protect the building from both inner and exterior fires compared to conventional glazed façades. Furthermore, the water layer helps in maintaining the glass panes at a uniform lower temperature and may not easily break due to the sudden cooling by the water sprayed by the firemen during a fire. It reduces property damages during the firefighting. However, knowledge on the fire performance of WWS is 
not available in the scientific literature. The assessment of the fire performance of a façade depends on the investigation of flame spread, smoke spread, and the potential damage. A hybrid fire simulation method with the fire performance of the WWS tested in the laboratory and the remaining building numerically simulated is beneficial [44], as it has the ability to study many aspects of fire propagation while avoiding the high costs of full-scale tests.

The objective of this paper is to review the existing literature on WWS and analyze the findings of the reviewed literature on the impact of WWS on the energy efficiency and fire safety of modern-day green buildings. Therefore, the central question of the review is formulated as "What is the state of knowledge on water wall system impacts on green buildings' energy efficiency and fire safety?" We formulated three sub-questions under the central question: 1. How do WWS affect energy efficiency? 2. How do WWS affect fire safety? 3. How suitable are WWS for green buildings? This paper discusses the applicability of WWS for both energy efficiency and fire safety, and in turn applicability for green buildings. This paper provides a useful reference for both industry practitioners and academics who are interested in WWS developments in order to enhance energy efficiency and fire safety in green buildings while maintaining occupant comfort. In addition, the paper provides the engineers in the construction field with an overview of WWS as a new concept which they can integrate into their building designs.

\section{Materials and Methods}

The authors selected the literature published up until August 2020 to conduct the review for this article. An overview of the literature search method is shown in Figure 1.

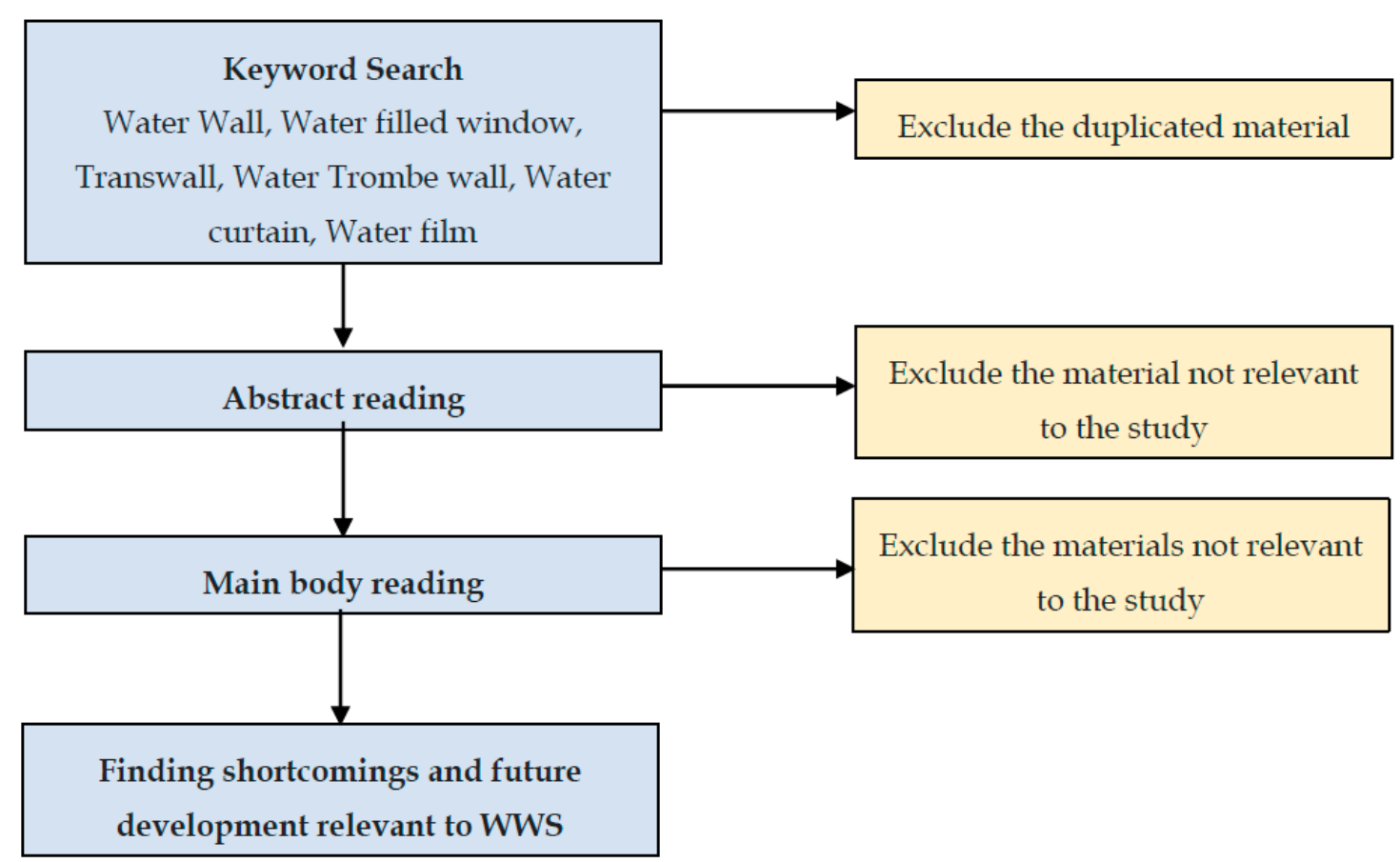

Figure 1. An overview of data collection and the selection procedure for the study.

The literature search process started with the defining of keywords. The keywords were defined after sample searches and sample paper reading. The keywords were Water Wall, Water filled window, Transwalls, and Water Trombe walls. All of these terms were synonyms or similar types of façade systems to WWS. Then the titles and abstracts of the search results were read to exclude the literature unrelated to the objectives of the research. The screened results were categorized according to energy-saving and fire safety. As there were no search results on the fire safety aspect 
of WWS; additionally, the key word Water curtain crossed with Fire safety was used to gain insight on fire safety from WWS. At last, the analysis of the contents of all the screened literature articles, books, chapters, proceeding papers, online publications, reports, standards, and theses revealed the up-to-date knowledge on the WWS performance for energy efficiency and fire safety, and uncovered the under-researched areas related to the application of WWS in green buildings.

The year-wise distribution of papers that resulted from a primary keyword search is shown in Figure 2. The literature search process started with the defining of keywords. The keywords were defined after sample searches and sample paper reading. The keywords were Water Wall, Water filled window, Transwalls, and Water Trombe walls. All of these terms were synonyms or similar types of façade systems to WWS. Then, the titles and abstracts of the search results were read to exclude the literature unrelated to the objectives of the research. The screened results were categorized according to energy-saving and fire safety. As there were no search results on the fire safety aspect of WWS; additionally, the key word Water curtain crossed with Fire safety was used to gain insight on fire safety from WWS. At last, the analysis of the contents of all the screened literature articles, books, chapters, proceeding papers, online publications, reports, standards, and theses revealed the up-to-date knowledge on the WWS performance for energy efficiency and fire safety and uncovered the under-researched areas related to the application of WWS in green buildings.

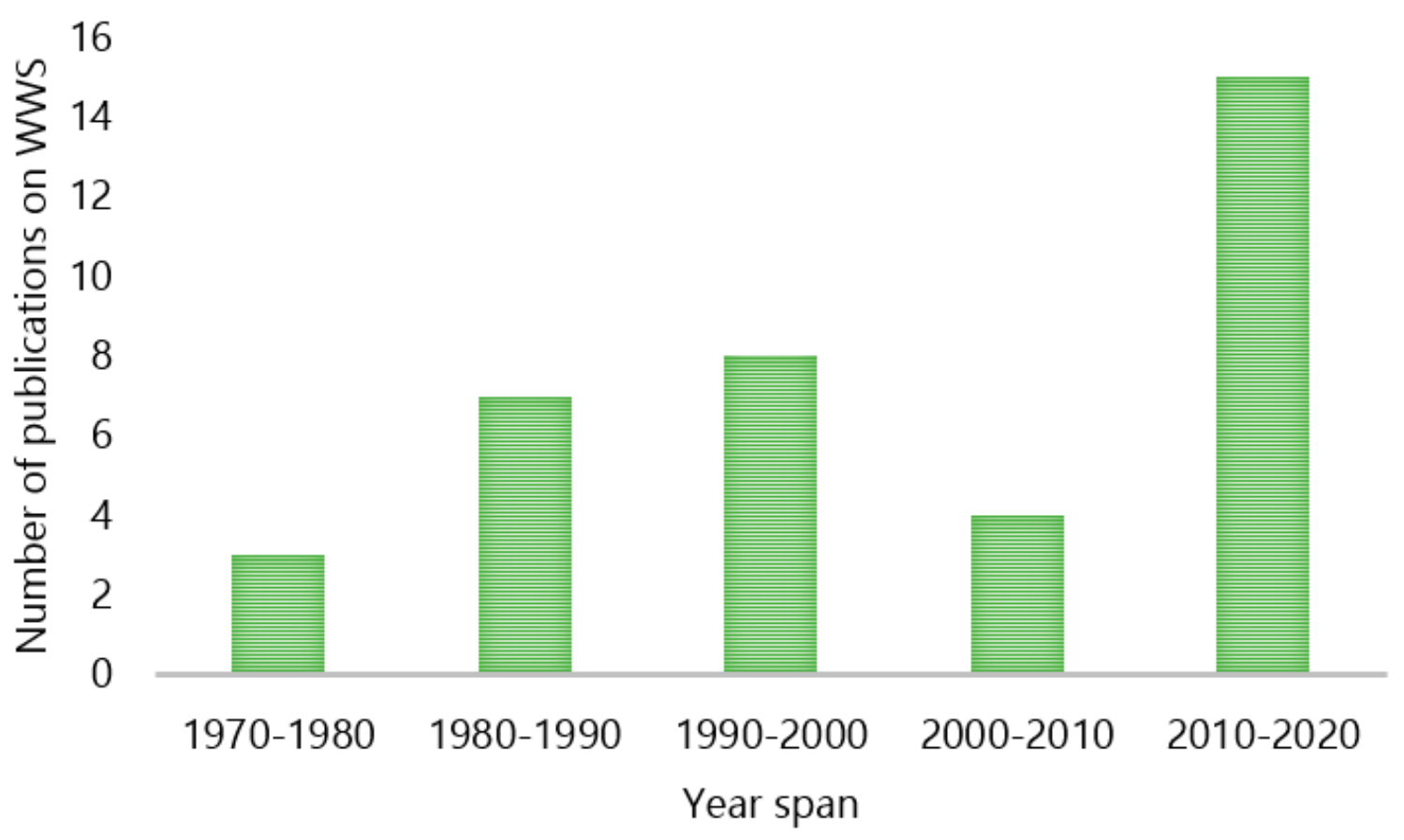

Figure 2. The number of publications under primary keyword Water Wall, Water filled window.

The year-wise distribution of publications that are specifically related to WWS emerged from the keyword search is shown in Figure 2. As shown in the figure, WWS has been under-researched for a long time, and there is an increasing trend on the WWS from the last decade.

\section{Water Wall Systems}

A Water Wall System (WWS) is "a façade that acts as a Thermal Energy Storage (TES) to store the heat energy for a specific period of time and release the stored energy later" [36]. It is capable of decreasing the energy consumption of buildings. There are different technologies used in TESs that can primarily be categorized as sensible heat storage and latent heat storage as per the heat storage medium. A latent TES retains or releases a significant amount of heat energy from the storage medium during the phase change cycle [45]. Sensible TES stores or releases heat energy with the storage medium's 
temperature change [46]. High thermal capacity materials like concrete, brick, or water are used in sensible TES to regulate the variations in temperature. Among these materials, water is more efficient in energy storage due to the high specific heat compared to other materials. Sensible TES is further classified into short-term and long-term. The short-term TESs store the heat energy throughout the day and release it at night, while long-term TES also operates for a seasonal period [46]. WWS falls under the short-term TES category and is useful in reducing the energy consumption of the building while preserving the occupants' thermal comfort.

\subsection{Evolution of Water Wall Systems}

The water wall built by Hoyt and his students (1947) in Massachusetts Institute of Technology in the United States using a series of 1.5 gallon cans, located behind a double-pane glass and painted in black, is claimed as the first recorded WWS in the world [47,48]. This WWS was able to provide $38-48 \%$ of the heating demand in the building. After some years, in Mexico, a school was designed with a large water tank for each building which serves as a water storage tank as well as a WWS. The buildings were stated to be very comfortable, but there are limited details available on this WWS. In 1972, WWS emerged back again in New Mexico in a space-age architecture designed by Steve Baer named Corrales house. This WWS was comprised of 55-gallon drums full of water, and as reported, this system worked very well. Steve Baer used water walls on both residential and commercial ventures. Many building designers were influenced by Steve Baer's work, including Jon Hammond, Tod Neubauer, Marshall Hunt, David Brianbridge, Marshall Hunt, and Denny Long, who did excellent water wall retrofit projects. In later stages, the water drums used for the energy storage have been replaced with thin water tubes made of different materials. At this stage, the commercial production of the WWS has been initiated. Further, the focus has been shifted for the designing of more aesthetical building elements, where the designers have recognized the glass as an attractive material for WWS. Figure 3 depicts the evolution of different types of water wall systems.

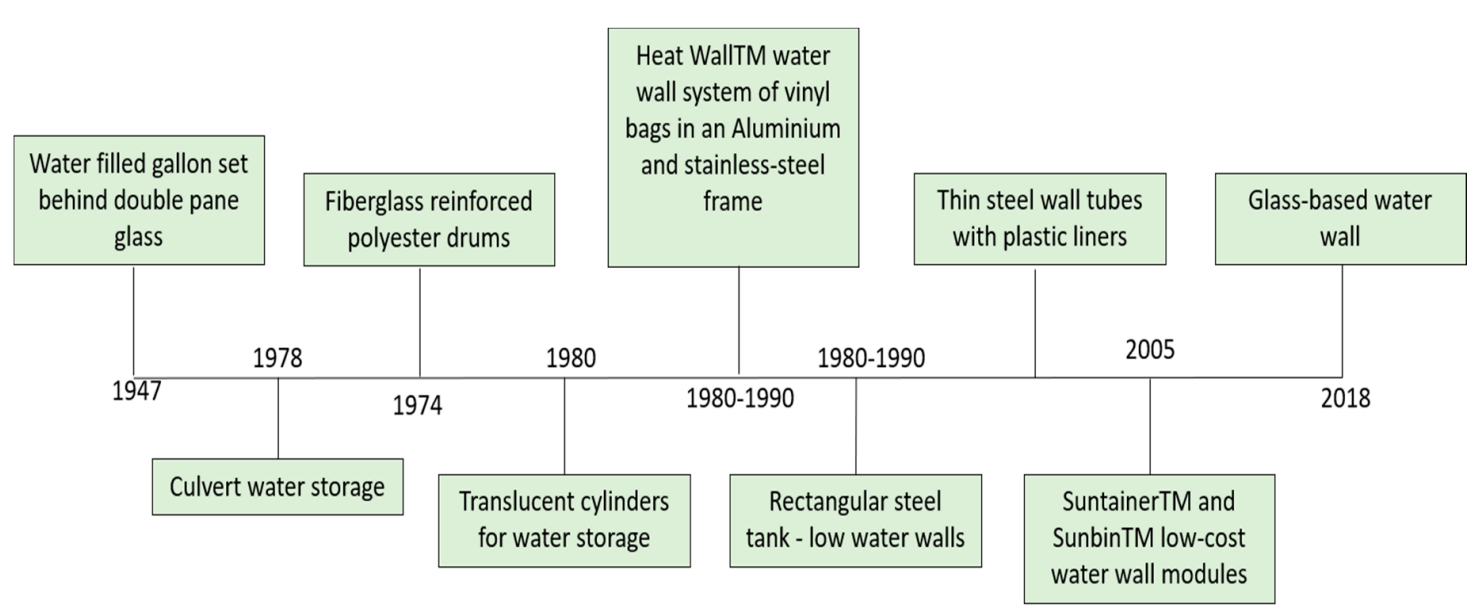

Figure 3. The evolution of water wall systems (WWS) $[49,50]$.

The designing of water walls in early days has mainly dispersed over the United States. However, research on WWS is becoming a trend in recent days, with much focus on energy performance all over the world. A more descriptive discussion on the research on WWS is present in Section 4.

\subsection{Classification of Water Wall Systems}

The WWS, as a façade component, has a long history. The development of WWS started with the introduction of water drums or containers to the building façade to act as a thermal mass. These walls were known as solar barrel walls. Since then, WWS has undergone several technological and design enhancements to cater for the growing needs of sustainable development. With these enhancements at 
present, the designs of WWS are much focused on the inclusion of water as a layer between two panes made of different materials. This pane material should be chosen for the construction purpose. Based on the position of the water wall within the building, "Water Wall Systems" can be mainly categorized into two types, as direct gain systems and as collaborative systems, as shown in Figure 4. In both, water acts as a thermal mass for heating and cooling.

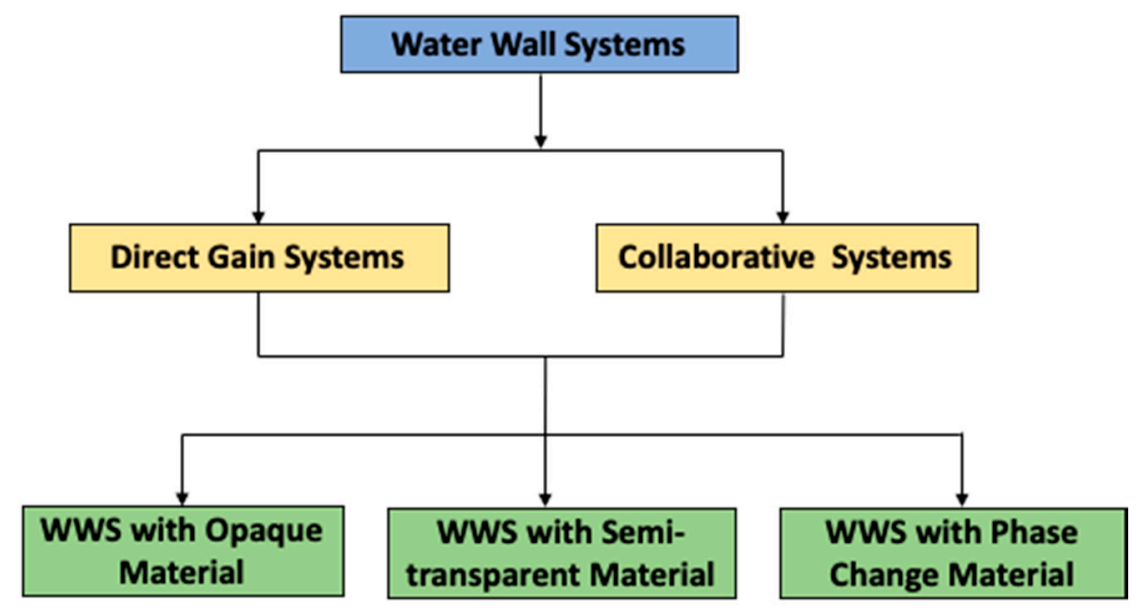

Figure 4. A categorization of WWS. Depending on the location within the building, the WWS are classified into direct gain systems and collaborative systems. This classification is further classified based on the material used in the WWS construction.

The basic categorization of WWS is direct gain systems and collaborative systems. In the direct gain system, the water wall directly faces the sun, and it is adjacent to the ambient. These systems receive solar energy without any intrusion, and heat collection, storage, and distribution all occur within the same space [51,52]. In the collaborative passive systems, the water wall is integrated with the other passive mechanisms for energy saving. It could be a sunspace, a solar chimney, a greenhouse, or a WWS with clerestory. The wall has dampers or vents at the base with the goal that colder air is drawn into the heated space between the glass and water wall. The heated air is drawn back into the building inside through the vents in at the top [53]. During the nighttime, the vents are closed, and the heat contained in the wall radiates into the building. WWS could be coupled with some other passive strategies, e.g., water wall combined with sunspace, and water wall combined with solar chimney. Sunspace and solar chimney are direct gain systems, while WWS is an indirect gain system. As revealed in previous studies, when a WWS and a sunspace or a solar chimney are combined, the thermal efficiency of the configuration is significantly improved.

Depending on the materials used in the building façade, a WWS is generally grouped into three types depending on the configurations: i.e., opaque WWS, WWS with a semi-transparent WWS, and WWS with Phase Change Materials (PCMs).

\subsubsection{Opaque Water Wall}

Opaque water walls are the basic configuration of water walls. In this configuration, a WWS is integrated into an opaque building façade that is a detached living space from the outer environment, for instance, concrete, metal plates, PVC pipes, and thermal insulating panes [35]. There are no outside viewing options with this configuration.

\subsubsection{Semi-Transparent Water Wall}

The WWS combined with a semi-transparent external façade, for example, light-porous plastic or glass, enables some portion of the daylight to infiltrate the WWS from outside. In this sort of system, the interior side of the WWS may be built with semi-transparent material or with opaque material. 
Depending on the material of the interior side, daylight can penetrate the room further. Transwall is a commonly used semi-transparent WWS which has a water layer in between two glass panes and a semi-transparent absorption plate at the middle In this kind of system, $80 \%$ of the incident solar radiation is absorbed by the semi-transparent plate and transmits the remaining 20\% [54]. This form of wall thus incorporates both direct gain and indirect gain techniques, and is ideal for areas with high daytime temperatures [55]. In this type of system, baffles have often been used to lessen the flow of convective heat through the walls. To improve water viscosity and avoid micro-organisms from growing, bio-inhibiting agents and gelling need to be included in the water [55].

\subsubsection{Water Wall with Phase Change Materials (PCMs)}

WWS could be coupled with Phase Change Material (PCM). The combination of the PCMs with WWS offers the benefits of both the WWS and the PCMs, thereby enhancing thermal efficiency. The configuration of PCMs with the water wall can have different arrangements as at the outer side, at the inner side, or both sides of the WWS. In the daytime, PCMs melt by absorbing energy from the surrounding environment and then re-solidify at night, releasing the stored energy. This process reduces the need for cooling in the daytime and heating at night $[56,57]$.

Depending on the above-discussed characteristics of different types of WWS, semi-transparent WWS allow more liberty for energy saving through thermal heat storage and daylighting options. Moreover, the semi-transparent WWS provide more design options for better aesthetic appearances compared to the other types. The following are the components of a semi-transparent WWS.

\subsection{Components of a Semitransparent WWS}

The essential components of a semi-transparent WWS are the two glazing panes and the water layer. The amount of heat transferred through the WWS mainly depends on the properties of these two components. Apart from these, the properties of objects used for fixing WWS into the façade such as frames, screws, nuts, and bolts, need to be considered in calculating the exact amount of heat transferred through the system. This section discusses the function of glass panes and a water column in a WWS.

\subsubsection{Glazing}

The glazing affects the efficiency of the WWS by controlling the transmission of solar radiation [58]. The material type, number of glass layers, and thickness of each layer are key attributes for designing a WWS [59]. Generally, the water temperature in a WWS is significantly reduced when the glass transmissivity is reduced from 0.9 to 0.45 [35]. Furthermore, the maximum daily temperature of the air in the attached room is significantly reduced with decreased glass transmittance, while there is not much change in the minimum daily temperature. In other research, reduced glass transmissions have been reported to prevent daytime indoor heating while preserving the required level of thermal comfort at night [60]. Thus, glazing has a direct impact on the performance of the WWS and is an essential consideration in designing the WWS.

\subsubsection{Water Layer}

The ideal water layer thickness of a WWS is correlated to the location of the building, latitude, and climate [52]. The thickness of the water layer has a direct impact on the performance of any kinds of WWS. With a dense layer of water, heat energy takes more time to penetrate the interior, creating thermal distress for the occupants in cold climate [61], but a high thick water column could result in smaller temperature fluctuations [37]. In contrast, a very thin water column can overheat the building's interior. Therefore, the optimum water column thickness must be determined before constructing the façade, as changing the water column thickness after constructing the building is technically difficult. 


\section{Energy Performance of Water Wall Systems}

The energy efficiency or the energy loss of a glass façade depends on the design of the glass façade and the glass material used in the façade construction. The façade should be able to allow the maximum light gain while limiting the heat gain to the building interior. The optimum combination of these two requirements is the key to the glass façade energy performance. The appropriate selection of glazing types for green buildings can result in a reduced space cooling load due to external impact as well as the reduced power consumption for air-conditioning and artificial lighting [60,62].

WWS increase the energy efficiency in buildings by reducing energy usage for heating, cooling, and artificial lighting (only for transparent and semi-transparent WWS) by creating transparent envelopes as shown in Figure 5.

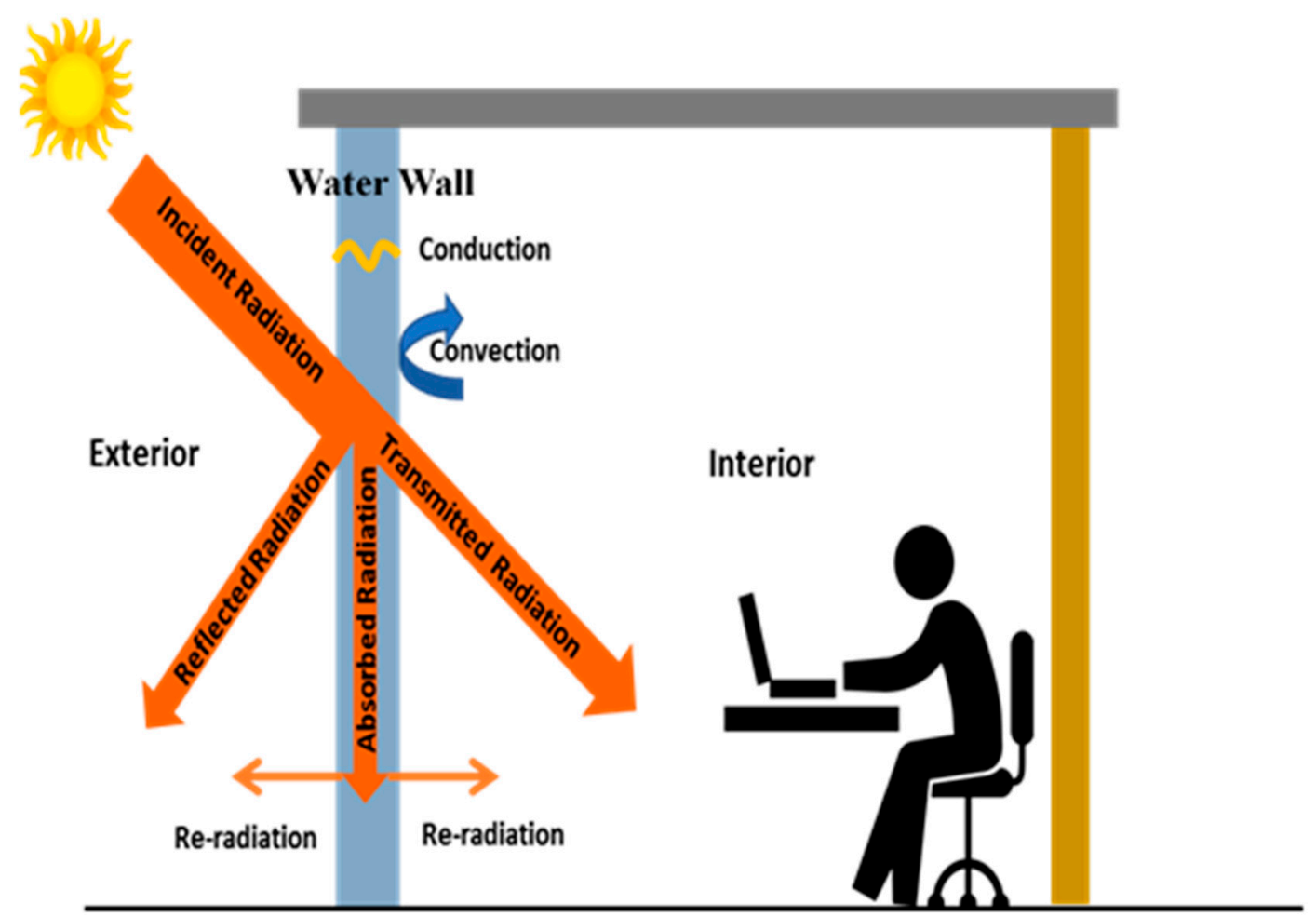

Figure 5. A Water Wall System as a building façade. A part of the solar radiation is transmitted through the glass in the daytime and heats the building interior. A solar radiation portion is reflected out of the glass. Part of the solar radiation is absorbed into the glass, conducted through the glass, and then radiated both inwards and outwards. This transmitted radiation lights up the room. Most of the heat transmitted into the wall reducing the heat transmission to the indoor environment.

The WWS's operational criteria is to increase the thermal comfort in the building interior against the annual environmental changes in the outdoor environment. This is accomplished mainly through the thermal mass gain of water, which has the ability to thermally stabilize envelopes in summer and reduce heat loss in winter through them. Besides, a transparent WWS helps in increased energy efficiency by maintaining an optical transparent stage all the time so that visible light can be transmitted directly through them during the day. In principle, the work of WWS depends primarily on the thermal and optical characteristics of the cavity filling materials. As shown in Figure 6, the solar energy incident on a semi-transparent water wall is partially absorbed and partially transmitted. The absorbed portion is eventually transported to the room while the transmitted fraction induces direct heating as well as daytime lighting in the room. When the outdoor temperature is declining in the nighttime, the WWS moderately heats the building interior [39] as shown in Figure 7. 


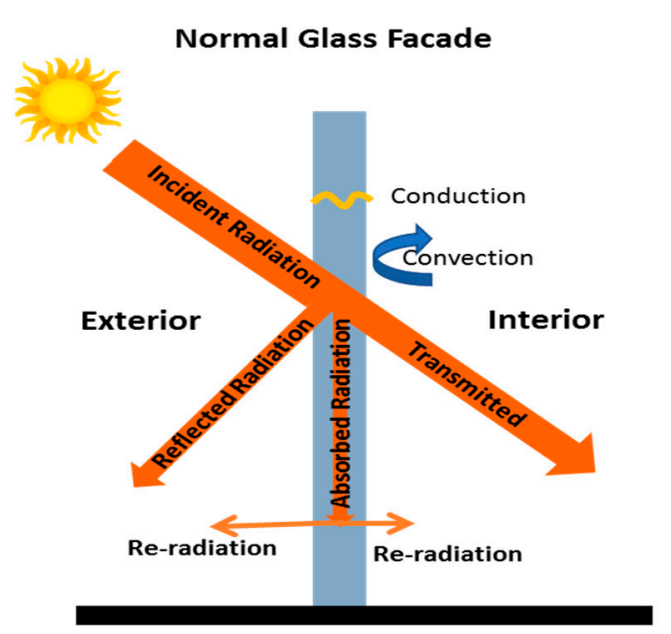

Most of the incident radiation is transmitted into the interior space

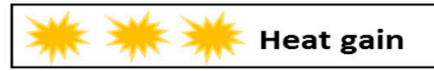

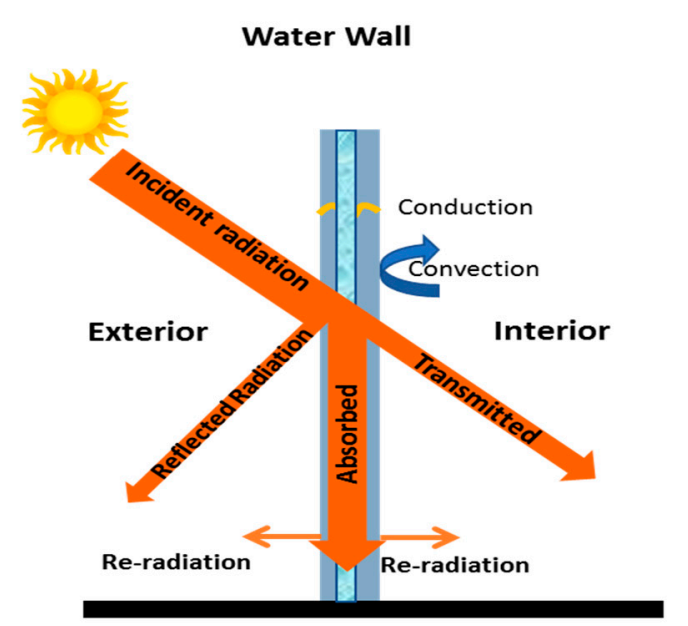

Most of the incident radiation is absorbed into the water column, thus less heat is transmitted into the interior space

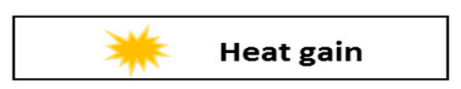

Figure 6. The heat gain through an ordinary glass façade vs. a water wall system.

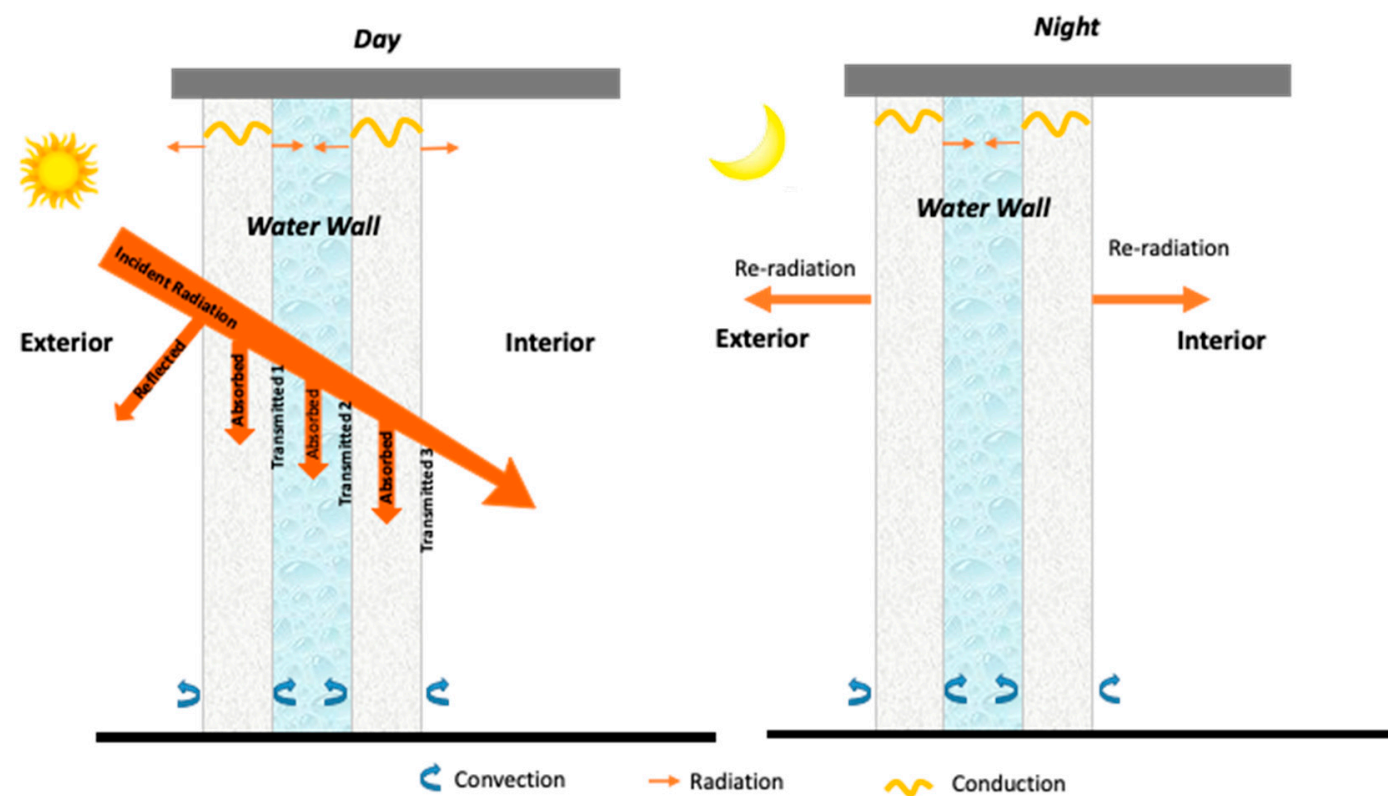

Figure 7. A water wall system stores the energy during the daytime and releases it during the nighttime.

\subsection{Past Research on Assessing Thermal Performance of WWS}

The review of the literature shows that researches on WWS were conducted in three different ways, namely, experimental modeling, an analytical method based on Heat Balance Models (HBM)s, and numerical modeling through Computational Fluid Dynamics (CFD) programs and Building Energy Simulation (BES) models. The following section discusses these methods in detail with examples from the literature. 


\subsubsection{Experimental Modeling of Thermal Performance of WWS}

The research on WWS started with the experimental modeling, whereas the history of experimental modeling of thermal performances of WWS could be traced back to 1947, which was conducted by Hoyt Hottel and his students [35]. However, after that, there are no records for the research on water walls until the 1970s. There is a significant number of researches carried out from the 1970s to the 2000s on WWS. Much of the water wall researches have been conducted using experimental modeling in the real climate conditions, while few were carried out in laboratories under controlled conditions. The results of a study conducted by Balcomb and Mcfarland [63] in 1977, comparing the performances of five different WWS configurations, suggested that the WWS located at the rear side of a glass pane and the WWS located behind a transparent insulation panel worked with considerably higher thermal efficiency than other configurations in winter. The other configurations were the WWS located inside the room with a temperature equivalent to the room temperature, the internal WWS located inside the room, and the WWS located behind an opaque wall. Nayak, Bansal, and Sodha [64], in 1981, confirmed that a semi-transparent WWS works more efficiently than a concrete wall in terms of thermal performance in the daytime in the Indian summer climates. The same study revealed that a water wall with a $0.10 \mathrm{~m}$ thick water column in between a $0.22 \mathrm{~m}$ thick concrete wall gives nearly a continuous heat flux into the room at nighttime. In 1986, Sutton and McGregor [65] compared the efficiency of a water wall with a concrete wall. The water wall was constructed with 27 galvanized steel tubes filled with water and a concrete wall of $300 \mathrm{~mm}$ (12in) thickness. The study showed a significant heating energy saving in the house with a WWS relative to the concrete-walled house. The house with WWS consumed $70.8 \%$ of the concrete-walled house's energy consumption. Another study was conducted by Turner et al. [66] in 1994 to show that during the summer daytime, the building inside could be cooled by a WWS made-up of $7.6 \mathrm{~cm}$ diameter plastics tubes mounted on a traditional wall which was charged by cold ambient air at night. The performance of a WWS combined with PCMs was investigated in 1988 by Yadav and Tiwari [67]. The results revealed that the combined effect of a WWS with PCMs gave the best thermal performance over all other WWS arrangements considered. In 2003, Din et al. [68] conducted a study on a WWS attached to a greenhouse to record the plant temperature, the water temperature, and the room temperatures for a day in the winter season by changing the factors such as absorptivity of the black colored WWS surface, water wall thickness, and the transmitted solar energy fraction. The results showed that a north facing WWS with a thickness of $27.5 \mathrm{~cm}$ could increase the room temperature by up to $4-5{ }^{\circ} \mathrm{C}$ at night and $3-4{ }^{\circ} \mathrm{C}$ in the daytime. In the later stages, the performance of water walls was assessed when they were combined with other passive systems. For example, in 1996, Tiwari and Singh [69] revealed that a semi-transparent water wall in a sunspace could reduce temperature fluctuations significantly, and in 2018, Wang and Lei [39] revealed that incorporating a water wall system to a solar chimney could result in an increased thermal comfort level in the attached room. For the literature reviewed, most of the previously conducted researches on WWS focused on the heating ability of WWS for summer seasons, where less attention is given to the performance of WWS for the winter season.

Experimental modeling in real atmospheric conditions has several advantages and several disadvantages [35]. Experiments allow for the gathering of real-time performance data, for instance, solar irradiation and angle, atmospheric temperature, wind velocity and direction, and the like. At the same time, the experiments are usually inflexible. When an experimental model is built up, it is typically troublesome or costly to adjust the model for various designs. Conversely, reduced-scale models might be flexibly adapted for different purposes. Furthermore, full-scale experiments are costly compared with the reduced scale laboratory experiments. Full-scale design models demand a large land area for the installation and entail substantial development expenses. If the experiment includes the study of seasonal weather changes from winter to summer or the other way around, it might take as long as a large portion of a year to finish the testing. Most importantly, it is typically challenging to rehash full-scale experiments under real whether conditions. Even though experimental modeling is considered a compelling method of studying the thermal performance of WWS [35], the numerous 
constraints of the experimental approach have kept it from being broadly practiced by researchers in the recent past.

\subsubsection{Analytical Modeling of Thermal Performance of WWS}

The analytical modeling of WWS has been conducted mainly through the Heat Balance Model (HBM)s and has been used for analyzing the performances of WWS in different types and different locations from the 1970s. In 1979, a group of researchers studied the thermal performances of a semi-transparent WWS, a Trombe wall, and a direct gain system using HBM, which they called thermal network models, and concluded the solar heat gain in a Transwall is very close to the solar heat gain of a Trombe wall [70,71]. Bansal and Thomas [72] in 1991 compared the performances of semi-transparent WWS, mass wall, solarium, and a Trombe wall using steady-state heat transfer equations and concluded that a water wall performs better than the others if night losses are reduced through the use of movable insulation. A similar type of research conducted by Bhandari and Bansal in 1994 confirmed that water walls and Trombe walls are more effective for marginally higher solar radiation applications [73]. Nisbet and Mthembu [74] in 1992 compared the performances of a WWS with dyed water and water-gel solutions with an HBM based on the Fourier conduction equation and revealed that WWS with water-dye solution has a high heat release at evenings. The same study showed that a Transwall installed in a house in the west of Scotland can have an energy saving of $23 \%$, while a fora house in the south of France is about $62 \%$. This study further revealed that the optimum wall thickness should be about $150 \mathrm{~mm}$ for a maximum performance.

The HBMs were also used for the analysis of WWS attached to different other passive techniques. It was revealed in 1988 by Yadav and Tiwari [75] that an opaque WWS incorporated in a sunspace in a residential single-story house could significantly reduce the temperature changeability in the space linked with the WWS. Tiwari and Kumar [76] compared the performances of an opaque WWS, a Transwall, and an air-collector in a sunspace using energy balances of the different components. The results revealed that a Transwall as a linking wall increases the room temperature on winter nights and outperforms the other two systems.

The HBMs also can configure the optimum thickness of WWS. In 1991, Upadhya, Tiwari, and Rai [77], who conducted a study in Sri Nagar, India, revealed that for maximum heat gain in the winter daytime with less temperature fluctuations, the thickness of the trap material needs to be maximized, while the inner pane glass thickness needs to be minimized. Wang and Lei [38] in 2019 investigated the optimum configurations for a WWS including different glass pane thicknesses, different air gap widths, different water column thicknesses, surface tinting, and the relative solar chimney location using a Transient Heat Balance Model (THBM). The results showed that increased glass pane thickness or reduced water column thickness could result in better thermal performance of the combined system, while increased air gap results in better ventilation with decreased room temperature.

The water wall researches in the recent past involved with the BES programs too. The majority of the studies have utilized the TRNSYS whole building simulation model. Wang et al. (2012) utilized TRNSYS to examine the energy utilization and thermal performance of an opaque WWS in China [78]. The simulation results of a year-round period revealed that building architecture can have an effect in reducing $8.6 \%$ of annual energy usage and can raise the thermal comfort assessment index by 12.9\%. Sánchez-Ostiz et al. [79] in 2014 simulated the energy performance of sunspace with an opaque WWS for both winter and summer climates using TRNSYS. The results of the study revealed that the energy requirement for the heating of a sunspace with a WWS was $12.9-16.7 \%$ less than a sunspace without a WWS. However, due to the limitations of the available BES programs, direct analysis is restricted to the opaque WWS. It requires external simulation programs such as CFD for the simulation of semi-transparent WWS.

In summary, much of the analytical research on WWS are based on HBM models, as it can foresee the essential elements of a building. However, these calculations are based on many assumptions, such as constant convective heat transfer coefficients, uniform surface temperatures, gray radiative 
surfaces, diffuse radiative surfaces, and one-dimensional heat transfer within the system. Furthermore, radiation interchanges between internal surfaces are often ignored in HBMs, while some models recognize the radiation released from external surfaces. However, $\mathrm{Wu}$ and Lei [36] showed that the internal surface-to-surface radiation exchange and time variations of heat transfer coefficients have a substantial impact on system efficiency. Due to these limitations of the models, the real performance of the system could be varied from the calculated performances.

\subsubsection{CFD Modeling of Thermal Performance of WWS}

The application of CFD modeling to WWS research is a new approach, and still a limited number of researches have been conducted by means of CFD modeling. Karabay, Arici, and Sandik [40], in 2013, researched the thermal efficiency of a concrete mass wall with built-in pipes filled with constant temperature water using CFD where turbulent water flow was presumed. The simulations were limited to steady-state conditions. In 2015, Moustafa and Aripin [41] assessed the steady-state thermal efficiency of a WWS combined with a porous ceramic pipes system, which is an advanced version of a potter wall. Coupling of BES tools with CFD is a growing research direction. In 2018, Sameti [80], with the use of TRNSYS, together with CFD, showed that the thermal efficiency of an opaque solar WWS with a water storage tank was higher in thermal performance than a conventional opaque WWS. Furthermore, a new thermal network model was developed by Liu, Guo, and Wang [43] and was used for the simulation of semi-transparent WWS through EnergyPlus together with a CFD study. The findings of these studies establish that the BES models together with CFD are useful in analyzing the energy performance of WWS in detail. Some recent studies have developed and used transient CFD models that considered the time effect of solar energy fluctuations and ambient temperature in evaluating the thermal efficiency of an opaque WWS and semi-transparent WWS [81]. However, many of the above researches have neglected the refractive radiation index and glass panes radiation reflection. These studies assumed a bulk value for the attenuation coefficient of solar radiation in water within the wavelength spectrum. However, in actuality, the attenuation coefficient of solar radiation in water depends on the wavelength. In this manner, a multiple-waveband attenuation model merits further research to get progressively precise outcomes. The evolution of WWS research is summarized in Table 1.

Table 1. A summary of past research on assessing thermal performance of WWS.

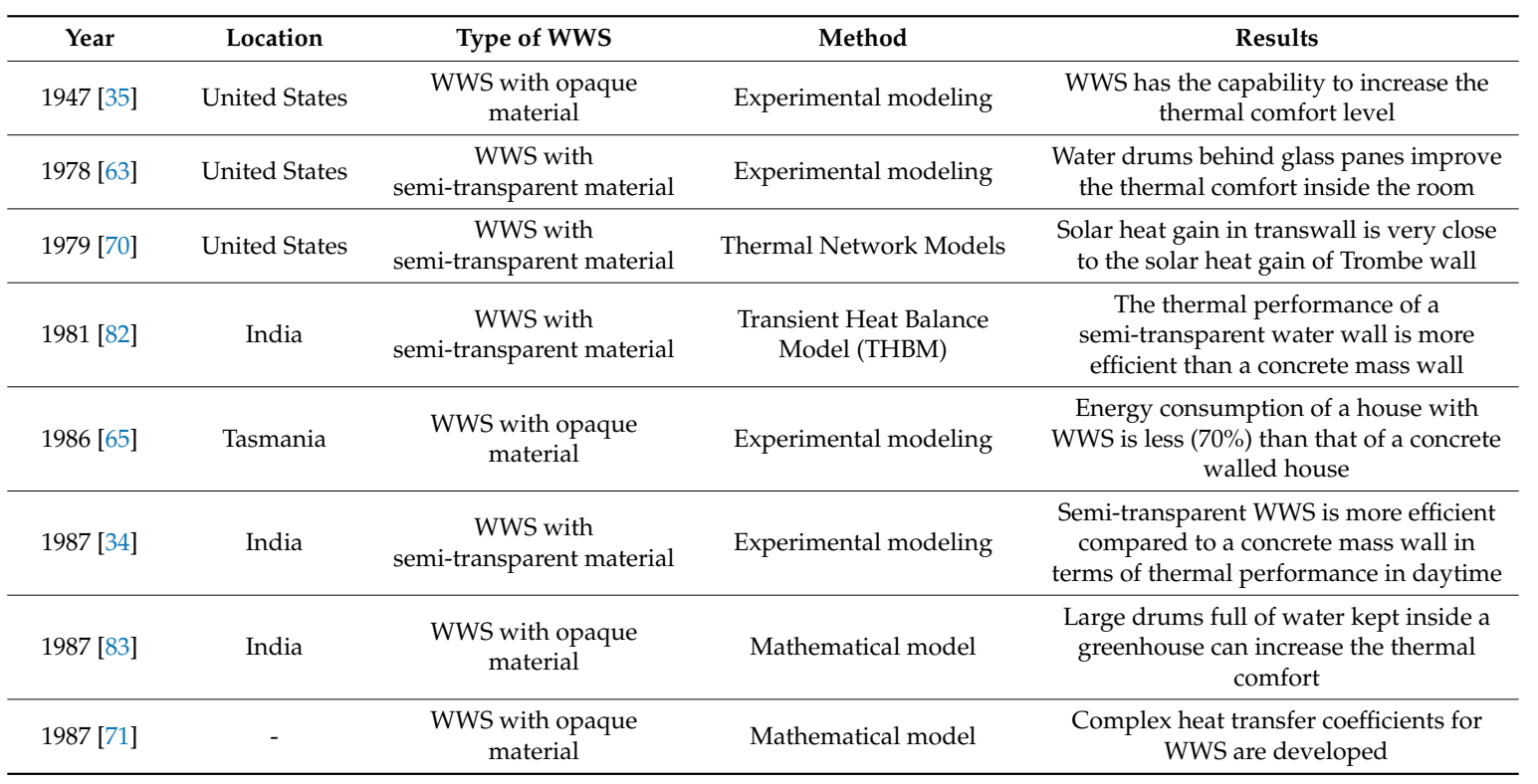


Table 1. Cont

\begin{tabular}{|c|c|c|c|c|}
\hline Year & Location & Type of WWS & Method & Results \\
\hline 1988 [67] & India & $\begin{array}{l}\text { WWS with Phase Change } \\
\text { Materials (PCM) }\end{array}$ & Experimental modeling & $\begin{array}{l}\text { Water wall combined with PCMs as a link } \\
\text { wall can increase the thermal } \\
\text { performance }\end{array}$ \\
\hline $1988[75,84]$ & India & $\begin{array}{l}\text { Collaborative-opaque } \\
\text { water }\end{array}$ & Heat Balance Models (HBM) & $\begin{array}{l}\text { The system reduces temperature } \\
\text { fluctuations inside the room significantly }\end{array}$ \\
\hline $1991[72]$ & Leh & $\begin{array}{c}\text { WWS with } \\
\text { semi-transparent material }\end{array}$ & THBM & $\begin{array}{l}\text { WWS performs better than the other } \\
\text { considered thermal energy storage walls }\end{array}$ \\
\hline $1991[77]$ & India & $\begin{array}{c}\text { WWS with } \\
\text { semi-transparent material }\end{array}$ & THBM & $\begin{array}{l}\text { WWS performs better than the other } \\
\text { considered thermal energy storage walls }\end{array}$ \\
\hline $1991[76]$ & India & $\begin{array}{l}\text { Collaborative-opaque } \\
\text { water }\end{array}$ & THBM & $\begin{array}{c}\text { For less temperature fluctuations with a } \\
\text { maximum heat gain, the inner pane } \\
\text { thickness of WWS should be at a } \\
\text { minimum }\end{array}$ \\
\hline $1994[66]$ & - & $\begin{array}{l}\text { WWS with opaque } \\
\text { material }\end{array}$ & Experimental modeling & WWS are efficient for summer days \\
\hline $1994[73]$ & India & $\begin{array}{c}\text { WWS with } \\
\text { semi-transparent material }\end{array}$ & THBM & $\begin{array}{l}\text { WWS performs better than the other } \\
\text { considered thermal energy storage walls }\end{array}$ \\
\hline 1996 [69] & India & $\begin{array}{l}\text { WWS with passive } \\
\text { mechanisms }\end{array}$ & Experimental modeling & $\begin{array}{l}\text { WWS reduces temperature fluctuations } \\
\text { inside the room significantly }\end{array}$ \\
\hline $2003[68]$ & India & $\begin{array}{l}\text { WWS with opaque } \\
\text { material }\end{array}$ & Experimental modeling & $\begin{array}{l}\text { A north-facing WWS with a thickness of } \\
27.5 \mathrm{~cm} \text { can increase the room } \\
\text { temperature by up to } 4-5^{\circ} \mathrm{C} \text { at night, and } \\
3-4{ }^{\circ} \mathrm{C} \text { in the daytime }\end{array}$ \\
\hline $2012[78]$ & China & $\begin{array}{l}\text { WWS with } \\
\text { semi-transparent material }\end{array}$ & TRNSYS & $\begin{array}{l}\text { WWS can decrease the room maximum } \\
\text { temperature by } 4^{\circ} \mathrm{C} \text { and increase the } \\
\text { minimum temperature by } 3^{\circ} \mathrm{C}\end{array}$ \\
\hline $2013[40]$ & Turkey & $\begin{array}{l}\text { WWS with opaque } \\
\text { material }\end{array}$ & $\begin{array}{l}\text { Computational Fluid } \\
\text { Dynamics (CFD) (FLUENT) }\end{array}$ & $\begin{array}{l}\text { The thermal performance of wall heating } \\
\text { systems is better than the floor heating } \\
\text { systems in terms of thermal performance }\end{array}$ \\
\hline $2013[88]$ & Spain & $\begin{array}{l}\text { WWS with } \\
\text { semi-transparent material }\end{array}$ & Experimental modeling & $\begin{array}{l}\text { The energy performance of WWS is more } \\
\text { effective than the traditional windows }\end{array}$ \\
\hline 2014 [79] & Spain & $\begin{array}{l}\text { Collaborative (Sunspace) } \\
\text {-Water wall in a sunspace }\end{array}$ & TRNSYS & $\begin{array}{c}\text { A sunspace with WWS needs } 12.9-16.7 \% \\
\text { less heating energy compared to a } \\
\text { sunspace without WWS }\end{array}$ \\
\hline $2015[41]$ & Luxor, Egypt & $\begin{array}{l}\text { WWS with opaque } \\
\text { material }\end{array}$ & CFD & $\begin{array}{l}\text { A pottery-water wall can reduce cooling } \\
\text { and heating demand by } 88 \% \text { at extreme } \\
\text { climatic conditions }\end{array}$ \\
\hline $\begin{array}{l}2015[89] \\
2017[90]\end{array}$ & China & $\begin{array}{l}\text { WWS with } \\
\text { semi-transparent material }\end{array}$ & CFD & $\begin{array}{l}\text { The effect of header design on the } \\
\text { performance of WWS is insignificant }\end{array}$ \\
\hline 2016 [37] & $\begin{array}{l}\text { Sydney, } \\
\text { Australia }\end{array}$ & $\begin{array}{l}\text { WWS with } \\
\text { semi-transparent material }\end{array}$ & CFD & $\begin{array}{l}\text { Greater energy savings of WWS in winter } \\
\text { climate compared to a concrete wall with } \\
\text { same thickness, and in summer they } \\
\text { perform in a similar way }\end{array}$ \\
\hline
\end{tabular}


Table 1. Cont.

\begin{tabular}{|c|c|c|c|c|}
\hline Year & Location & Type of WWS & Method & Results \\
\hline 2018 [80] & - & $\begin{array}{l}\text { WWS with } \\
\text { semi-transparent material }\end{array}$ & TRNSYS + CFD & $\begin{array}{l}\text { The proposed system is high in thermal } \\
\text { performance and aesthetic appearance }\end{array}$ \\
\hline 2019 [91] & $\begin{array}{l}\text { United States, } \\
\text { Chicago }\end{array}$ & $\begin{array}{l}\text { WWS with } \\
\text { semi-transparent wall }\end{array}$ & $\begin{array}{l}\text { Integrated Energy (IE) and } \\
\text { CFD }\end{array}$ & $\begin{array}{l}\text { Transparent water storage envelopes can } \\
\text { result in } 70 \% \text { of heating and cooling load } \\
\text { reduction compared to conventional glass } \\
\text { facades }\end{array}$ \\
\hline 2020 [92] & 13 cities & $\begin{array}{l}\text { WWS with } \\
\text { semi-transparent wall }\end{array}$ & $\begin{array}{l}\text { Window Program }+ \\
\text { TRNSYS }\end{array}$ & $\begin{array}{l}\text { WWS can result in energy saving of } \\
3-84 \% / \mathrm{US} \$ 0.99-24.25 / \mathrm{m}^{2} \text { based on the } \\
\text { climate }\end{array}$ \\
\hline
\end{tabular}

The WWS is proven to be a potential building element to increase thermal performance and energy efficiency on a limited scale. The location of the WWS has a significant effect on the performance level, as the heat transfer through the system heat storage depends on the incident solar flux on the external side of the façade. However, as shown in Table 1, the WWS researches have been performed only in several countries, including the United States, India, China, Australia, and several other European countries. These researches have been carried out in small scales with prototype models, and the research results for the thermal performance of WWS in real buildings are limitedly available in the literature. This may be a reason for the limited application of WWS in real building projects. The research methods on WWS has evolved from experimental modeling and analytical modeling to CFD and whole-building energy simulations. In the majority of these researches, the CFD calculated values for the temperature of the surfaces and water have used as input data for the BES packages. This is because many of the available BES are not equipped with the capability of direct simulation of WWS. Having a direct simulation program may increase the WWS in real building applications, as then the building designers can design WWS for the advancement of energy efficiency and thermal performance in buildings.

The energy efficiency considerations have overlooked the effect of embodied energy throughout the building life cycle. The embodied energy calculation considers the energy use for extraction/manufacturing of materials, transportation, construction, maintenance, replacements during the entire life cycle, and the disposal of the system. If more energy is consumed in these phases of the WWS lifetime, the embodied energy can overperform the reduced energy consumption for air conditioning of the building. Therefore, the comparison of embodied energy against the expected energy savings is very much needed for the real building applications.

The future research directions concerning the energy performance of WWS are discussed in Section 7.

\section{Fire Performance of Water Wall Systems}

A building façade should be planned to limit the spread of fire to the inside of the building built to restrict fire spread inside the structure, to the adjacent floors, and to the outside of the building, allowing the evacuation of building occupants and ensuring the safety of the rescue team [93]. Moreover, the façade needs to be constructed in a manner that stops parts from collapsing throughout the evacuation and rescue team activities. However, a standard glass façade is more vulnerable to fire spread than a conventional façade made with bricks, stone, or concrete, and can easily break within a matter of minutes [94-96] when exposed to fire. This collapse of glass panes introduces a new airflow for fresh air and fire spread outdoors, enabling the phenomenon of flashover or backdraft [97]. Compartment fire dynamics may be drastically modified, triggering more serious disasters $[98,99]$. The possible ways of fire spread through a glass façade are elaborated in Figure 8. 


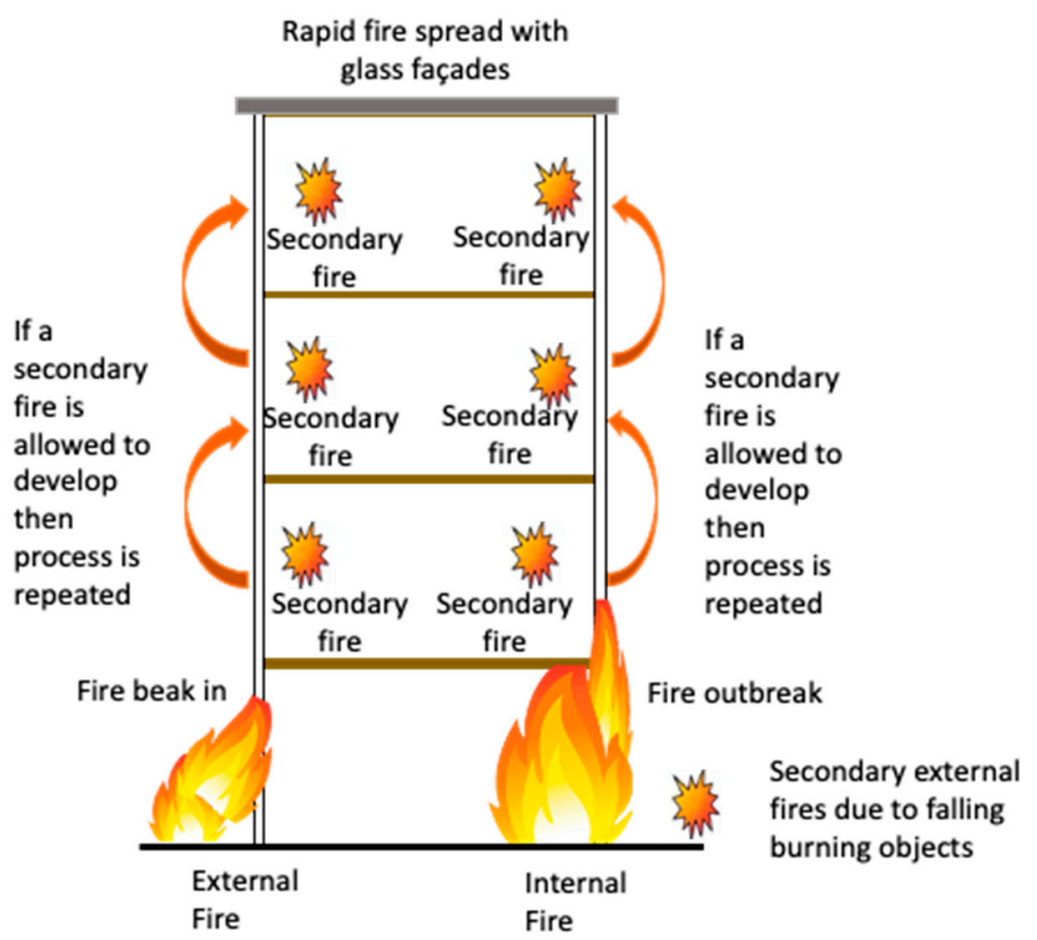

Figure 8. Rapid fire spread with glass façades. Potential fire risks for a building in fire accidents may come from foreign or local agents. For external causes, the fire may spread from nearby buildings or a firing item in the local environment. The radiation coming from the external fire can develop the thermal stress on the glass and can break the glass. Then the fire enters the building interior. Fire accidents from interior fire sources are more common in the real world, where the fire propagates from room to room/floor to floor. The internal fire can develop the thermal stress on the glass, and then the glass breaks. Then the flame will hit the upper floor façade, and the secondary fire will develop. The fallen burning objects can develop another secondary fire.

Glass façade fire performance is influenced by many factors, while thermal gradient is the primary cause of glass breakage [100]. Several researches have been carried out on the crack ignition of glass panes in a fire, and different results are established. For example, Keski-Rahkonen [101] revealed that an $80^{\circ} \mathrm{C}$ temperature variance between the heated glass pane and the edge is needed for crack initiation. Pagni and Joshi $[31,102]$ reported that only a $58^{\circ} \mathrm{C}$ temperature difference is needed for crack initiation in a glass pane. Moreover, it is established that the fallout of a glass pane when exposed to fire also depends on the imposed heat flux. For example, a single-strength glass pane will crack with 4 to $5 \mathrm{~kW}$ $\mathrm{m}^{-2}$ of heat fluxes [103]. However, in a real fire situation, it is difficult to predict when the glass will fall out after breakage [100]. The glass pane thickness is another significant factor that affects the glass pane performance in a fire. For example, $3 \mathrm{~mm}$ window glass panes break at a temperature of around $360^{\circ} \mathrm{C}$. For thicker, 4-6 mm glass pane, the glass pane will break at around $450{ }^{\circ} \mathrm{C}$, and double-glazed glass panes with a $6 \mathrm{~mm}$ thickness are expected to break at about $600{ }^{\circ} \mathrm{C}$ [100]. It has also been proven with several experiments that the temperature differences required for glass pane cracking will increase with increasing thickness [28]. The type of glass pane selection, such as single pane/double pane, also has a significant effect on the glass fire performance [28,104,105]. Besides, the smoke movement [98], glass pane orientation $[28,30,99]$, and location of the fire [30] are found to be of considerable significance for glass pane breakage [14].

The characteristics of WWS make itself potentially a fire safety construction element. Water is used to extinguish flames. Especially water film and water curtain are used on glass panes to prevent breakage [106-109] since glass breakage influences the fire spreading, as explained previously. However, glass cracking typically happens in the rapid cooling phase rather than the rapid heating process, 
owing to the thermal shock induced by sudden cooling, which is a problem associated with water films and water curtains [110]. This issue can be overcome by a WWS, as a WWS always has a continuous water layer between two glass panes. The heat passes through the interior or exterior glass pane and is absorbed by the water column from the fire initiation. Therefore, it is reasonable to expect that to heat up the glass pane until its breakage stage will take a longer time. The WWS offers abundant faster heat exchange than a typical wall fabricated from concrete or brick because the heat stored in water could also be decentralized through convection. Compared with other building materials, water has a high specific heat capacity of $4.2 \mathrm{~kJ} / \mathrm{kg} . \mathrm{K}$, while concrete has a specific heat capacity of $0.880 \mathrm{~kJ} / \mathrm{kg} . \mathrm{K}$ only [111]. With the water layer, the glass panes are maintained at a lower and perhaps more uniform temperature and will not be easily broken by the water sprayed by a fireman during a fire. The mechanism by which a WWS enhances fire safety is shown in Figure 9.

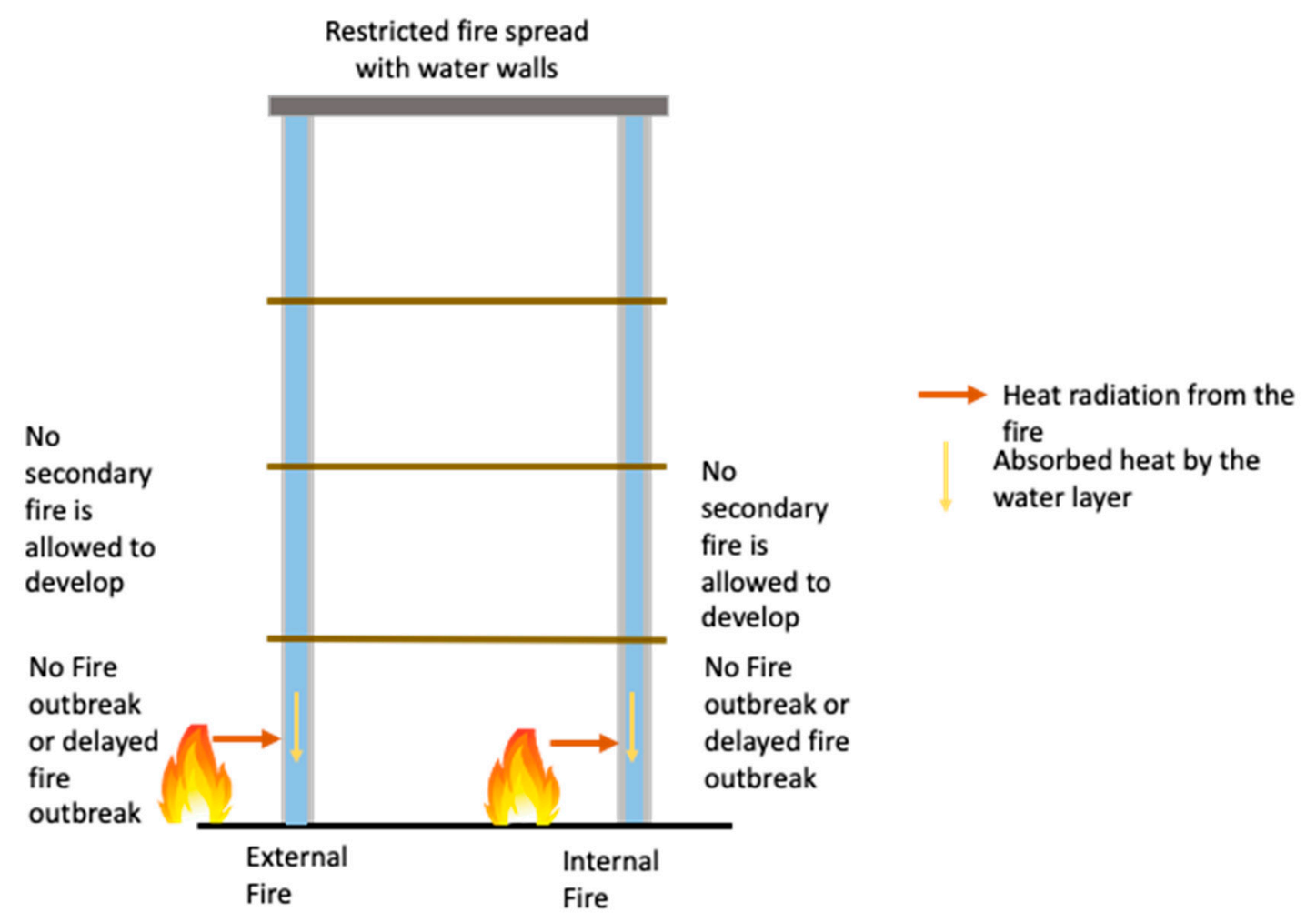

Figure 9. Restricted fire spread with water wall systems. The water layer traps the heat transmitted and conducted through the glass panes from the inner fire or the exterior fire. As the added heat from the fire is transferred to the water layer, the glass panes are heated up more slowly during a fire, delaying breakage of glass panes due to heat up. With this effect, the WWS protects the building from both interior and exterior fires.

\section{Water Walls as a Green Building Façade}

A green building needs to be more friendly with the environment and humans than conventional buildings [112]. For this, a green building must be designed, constructed, restored, managed, or recycled in an environmentally friendly, economical, and resource-efficient way [113,114]. It is expected to meet a range of particular targets: Energy efficiency, reduced $\mathrm{CO}_{2}$ and Green House gas, pollution control, noise reduction, enhanced indoor air quality, and environmental harmonization. In this context, water walls are well suited for the green building façades [114]. 


\subsection{Economic Cost of WWS}

WWS are considered as simple and very economical for many reasons. WWS may also be built in new or renovated buildings with traditional construction techniques. WWS do not depend on auxiliary power, as no pumps or valves are incorporated. Therefore, WWS operate even though the electricity is off, which helps in reduced energy bills. Constructing and maintaining a WWS is less costly than other thermal storage systems, since WWS is constructed with standard materials and also has a long life [38]. For example, a water wall will cost about $\$ 9612$ for 100,000 BTU storage, while a concrete wall will cost about $\$ 14,426$ for the same heat storage in San Francisco, CA, USA [50]. Thus, WWS is more economical than that of concrete walls for constructions in San Francisco, CA, USA. As the economic cost of the building elements may vary for different locations, the economic cost needs to be calculated before the building design. However, depending on the lower material volume, ease of construction, lower maintenance needs, and the reduced energy consumption, it is expected that WWS are economical on the whole worldwide than that of high thermal mass façades such as concrete walls.

\subsection{Embodied Energy of WWS}

The embodied energy of WWS (which is the total energy required for extraction of raw materials, processing of WWS, delivery and construction of WWS, and the disposal after the building demolition) needs to be considered in assessing the suitability of WWS for green buildings. The embodied energy of a WWS primarily depends on the embodied energy of glass, as a WWS is built of two glass panes and a water layer. A material-wise comparison of the embodied energy of a WWS and a concrete wall is shown in Table 2. In all the selected countries, float glass has a much higher embodied energy than concrete for a unit mass. However, for effective comparison, embodied energies need to be compared on a per area basis for façade elements.

Table 2. A WWS embodied energy comparison against a concrete facade for different countries.

\begin{tabular}{ccccc}
\hline Location & $\begin{array}{c}\text { Glass Embodied } \\
\text { Energy per Unit } \\
\text { Mass (MJ/kg) }\end{array}$ & $\begin{array}{c}\text { Concrete-Embodied } \\
\text { Energy per Unit } \\
\text { Mass (MJ/kg) }\end{array}$ & $\begin{array}{c}\text { WWS Embodied } \\
\text { Energy per } \mathbf{1} \mathbf{~ m}^{\mathbf{2}} \text { of } \\
\text { the Façade (MJ) }\end{array}$ & $\begin{array}{c}\text { Concrete-Embodied } \\
\text { Energy per 1 } \mathbf{~ m}^{\mathbf{2}} \text { of } \\
\text { the Façade (MJ) }\end{array}$ \\
\hline Western Australia [115] & 15 & 1.39 & 885 & 1737.5 \\
\hline New Zealand [116] & 15 & 2 & 885 & 2500 \\
\hline USA [117] & 12.7 & 1.5 & 749.3 & 1875 \\
\hline
\end{tabular}

The thickness of façade elements is usually decided based on the structural requirements and the required U-value of the building envelope, which determines the amount of heat transfer through the building envelope. The U-value of a building element depends on the thermal conductivity of the material, convection coefficient from the material surface, and the thickness of the building element. For example, a WWS with $100 \mathrm{~mm}$ water layer and two $25 \mathrm{~mm}$ thickness glass panes has a U-value of $1.08 \mathrm{Wm}^{-2} \mathrm{~K}^{-1}$. In order to have the same U-value, a concrete wall needs to have about $400 \mathrm{~mm}$ thickness. The mass of glass required for the construction of a WWS facade is lower than the mass of concrete for a comparable concrete facade. A comparison of the embodied energy of WWS and a comparable concrete wall is presented in Table 2 and Figure 10. 


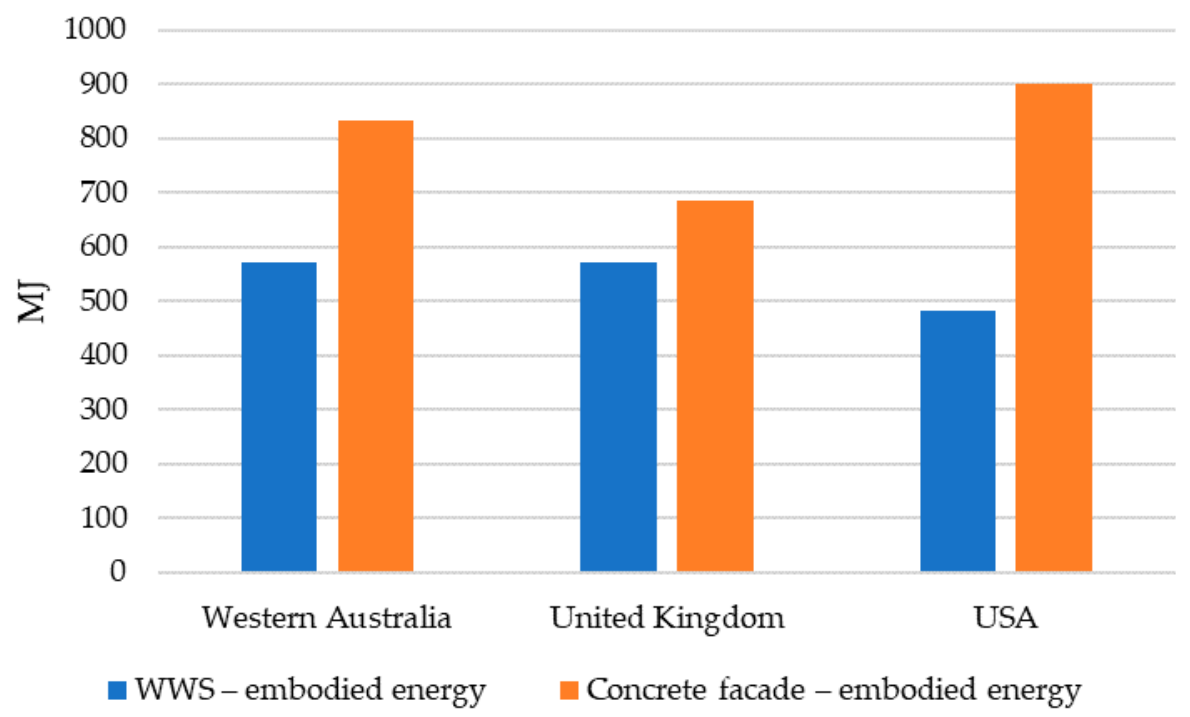

Figure 10. A WWS embodied energy comparison against a concrete facade for different countries (per $1 \mathrm{~m}^{2}$ of the façade) (Sources: [115-117]).

As shown in Figure 10, even though the embodied energy value of WWS differs for different locations, it is always less than the embodied energy of concrete walls. Thus, WWS is a more sustainable feature than a concrete wall for a green building, considering the fact that the embodied energy of WWS is lower than that of the concrete facade on a unit area basis.

\subsection{Energy Consumption and Greenhouse Gas Emissions}

WWS decreases the heat loss and heat gain through the building facade, thus lowering energy usage for air conditioning. On the other hand, WWS get a large amount of light that aids in giving a high measure of natural daylighting as opposed to depending exclusively on artificial lighting [118], thereby reducing the energy consumption for artificial lighting $[119,120]$. The mechanism of energy saving through WWS has been explained in detail in Section 4.1.

The reduction of $\mathrm{CO}_{2}$ and GHG emissions is one of the major purposes of green buildings to reduce the impact on the environment $[17,19,121]$. As energy consumption is reduced, the need for energy generation is also reduced. Consequently, fewer fossil fuels are burned for electricity generation reducing $\mathrm{CO}_{2}$ and GHG emissions. Furthermore, during a fire, the WWS absorbs much of the heat radiation from the fire, thus reducing the thermal stress development on the glass pane. This helps in preventing more hazardous fire situations. The reduced fire risk also effects in reducing the possibility of $\mathrm{CO}_{2}$ emissions.

\subsection{Recyclability}

The suitability of a material to match with the green concept needs to be evaluated by considering the entire life cycle, including construction and demolition. Glass panes are comprised of non-contaminating raw materials, has an energy-efficient manufacturing process requiring an insignificant amount of water, and creates a negligible amount of waste [122,123]. Its application in the structures chops down the use of concrete, which is again one of the primary sources of $\mathrm{CO}_{2}$ generation. Additionally, glass panes are recyclable and can be reused, offering to ascend to a Cradle to Cradle approach [114], which makes it a clear choice that is causing a decrease in raw material needs.

\subsection{Human Friendliness}

A green building needs to be human friendly. Thermal comfort, acoustic comfort, and aesthetic appearance are some of the factors that affect human friendliness. As the temperature fluctuations 
within the buildings are reduced, the WWS deliver thermal comfort to the occupants. Furthermore, WWS provides a high level of acoustic solace by warding off sound from the outsides to the insides, thus guaranteeing a more quiet atmosphere inside [124]. WWS provides natural views to prevent claustrophobic experiences of complete masonry walls [125-127]. It is reported in the previous researches that better viewing options of the outside can lead to the improvement of the health and wellbeing of humans, which is possible with WWS [128,129]. Meanwhile, water is not toxic, contrary to other TES substances such as PCMs. Therefore, WWS are environmentally safe and human friendly.

Owing to the above-discussed design and working principle, it is fair to conclude that WWS is innovative, environmentally beneficial, economical, and socially approachable, and an excellent sustainable application to a green building façade. Figure 11 portrays the green benefits of water wall systems.

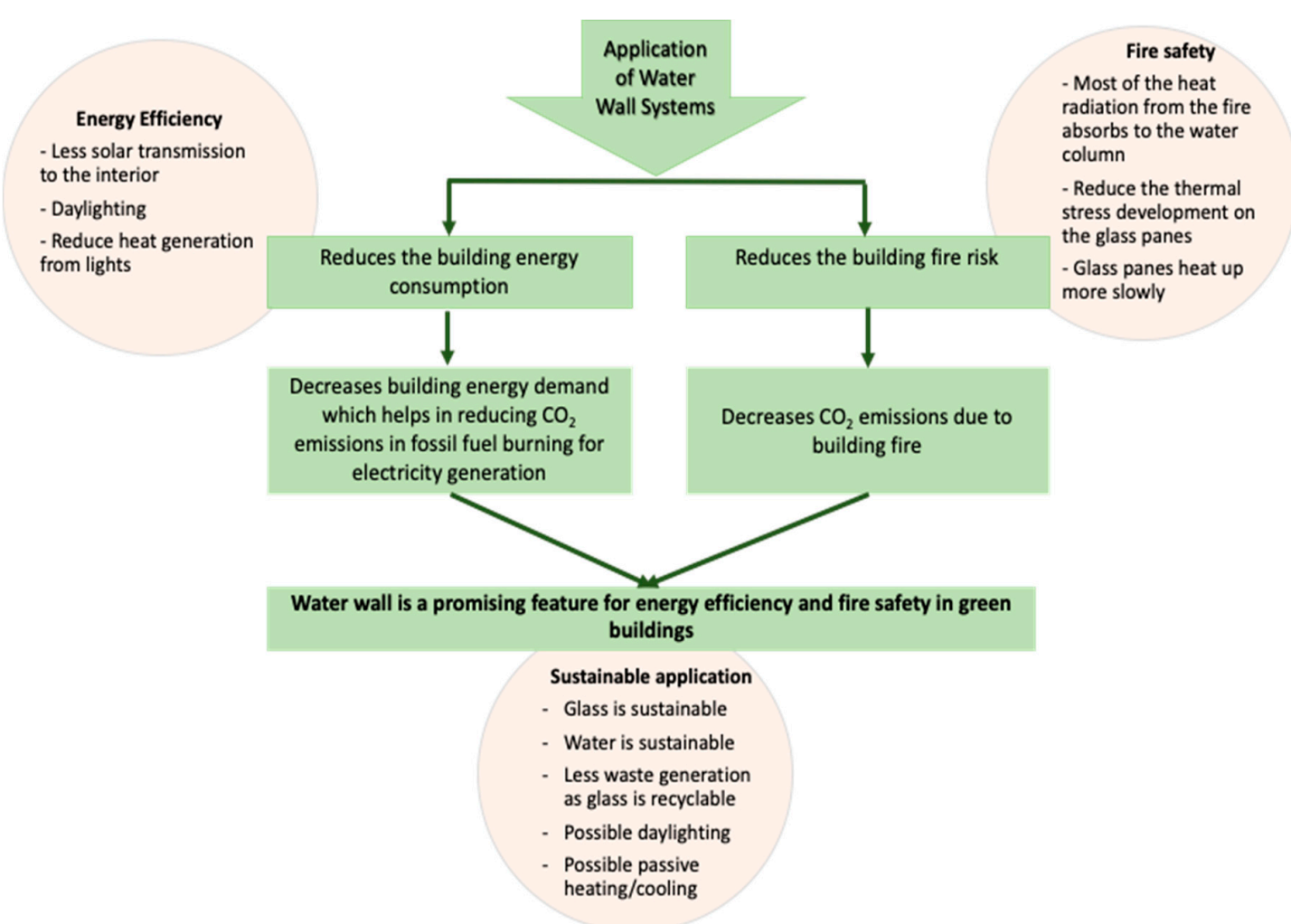

Figure 11. A water wall is well suited for a green building façade. The application of water wall systems helps in reducing building energy consumption and fire risk. Water wall systems help to reduce the building heat loss and heat gain, allow daylight within the daytime, and thereby reduce the energy consumption for air conditioning and artificial lighting. Consequently, fewer fossil fuels are burned for electricity generation. In a fire situation, the WWS absorbs much of the heat radiation from the fire, slowing down the glass pane heat up and reducing the thermal stress development on the glass pane. The reduced fire risk and reduced electricity generation effects in reducing the possibility of $\mathrm{CO}_{2}$ emissions, which is one of the main aims of green building constructions. Further, the material used in WWS constructions are sustainable and recyclable.

\section{Shortcomings of Past WWS Research and Future Directions}

A considerable number of researches have been carried out on assessing the energy performance of different types of WWS. However, there is a gap in the literature assessing the economic cost of WWS. In fact, assessing the cost of WWS is important for before applying to the green buildings, as the economy is one pillar of sustainability, with the environment and humans being the remaining pillars. It is a common perception in the construction industry that "Green costs more". This is one 
of the reasons that WWS are limitedly applied in buildings worldwide. Therefore, to foster WWS developments in worldwide, studies on the economic aspect of WWS is a deliberate need.

The reviewed literature reveals that the application and the research on WWS are limited only to several countries. The results of those researches suggest that the efficiency of the system significantly varies with the climatic conditions, which cannot be generalized to the whole world $[77,82,130,131]$. Future studies should concentrate on the best WWS configuration concerning each climatic condition around the world. The results can increase the popularity of WWS in the global context.

Past research suggests some parameters (water wall type, the material used, location of the WWS in the building, size of the WWS) influence the effectiveness of WWS significantly. By modifying one or two of these parameters, WWS' overall efficiency could be greatly strengthened. To this end, future research is crucial to find the optimal design mix for the effective operation of the WWS.

The previous studies confirm that the incorporation of WWS into the buildings could result in reduced temperature fluctuations in most of the countries concerned. However, the impact of reduced temperature fluctuations on the energy efficiency of the building has been barely studied. Therefore, future research should focus on assessing the whole building energy saving with the integration of WWS to the building. The results will attract the general public for the WWS application.

Furthermore, this literature review reveals that BES programs are beneficial in assessing the performance of passive energy systems. Numerical simulation is more effective than prototype testing in research. Nonetheless, WWS cannot directly use the available computational envelope components or window components in current energy programs, such as Equest, EnergyPlus, IES-VE, TRNSYS, and TAS [132]. Since envelopes are predefined as opaque surfaces, it is unable to perform WWS simulations as a façade component directly, as it does not consider the light transmission to the indoors. In addition, window modules of most of these energy programs are standardized as objects without thermal mass parameters; thus, heat transfer is often measured without heat storage, which is crucial for the WWS operation. Therefore, the development of BES programs to assess the energy performance of WWS should be focused on by the future studies. This provides the likelihood of simulating advanced building environments over an extended period in merely several minutes. It is less time consuming, and inexpensive. Therefore, it is incredibly useful in finding out large-scale systems over extended periods of time, and having a whole building simulation enables proper building designs with WWS.

In addition, WWS could be connected to other green building elements such as green roofs. The integration could result in increased benefits. However, the evidence of such assessment lacks in the reviewed literature. Moreover, the embodied energy of WWS needs to be considered in assessing the suitability of WWS for green buildings. If more carbon emissions are associated with WWS applications, it is a detriment to the green building concept. Therefore, future research should assess the embodied energy of WWS and compare the efficiency of integrating WWS with other green building features.

As suggested in Section 5, depending on the characteristics of the WWS, it is fair to assume that the WWS can provide fire protection to the buildings which have not yet been investigated in the scientific literature. Therefore, more realistic studies are required to examine the WWS contribution to fire safety. The assessment of the fire performance of a façade depends on the determination of the flame spread, smoke spread and the potential damage. A hybrid fire simulation approach in which the WWS fire efficiency is measured in a fire testing facility while the remaining building is numerically simulated at each stage is advantageous [44], as it has the ability to study many aspects of the fire propagation, avoiding the high costs of full-scale tests.

The designing and construction of passive solar systems, such as WWS, are challenging [51]. The cost of installation and maintenance, lack of trained technical personnel, and no established building codes addressing the design and operation of WWS are some of the challenges associated with the limited use of WWS. However, the life cycle benefits of the system will outgrow the cost of installation and maintenance, and the proper design decisions for WWS will help to keep their installation and maintenance costs at a minimum. Thus, correct technical knowledge is essential 
in constructing a WWS [48]. When the systems are installed incorrectly, it creates additional risks. If a building system has established performance-based building codes, it helps in constructing more efficient systems. Therefore, future research should aim at the establishment of building codes concerning the WWS.

Provided their possible long-term advantages, WWS tend to be cost-effective. WWS will have long-term ecological, socioeconomic, and environmental advantages to make communities safer, healthier, and more prosperous. A systematic analysis of WWS long-term benefits worldwide is expected in future studies. Long-term evaluations might provide significant evidences to enable stakeholders to participate in large-scale WWS programs.

A summary of future research directions is shown in Figure 12.

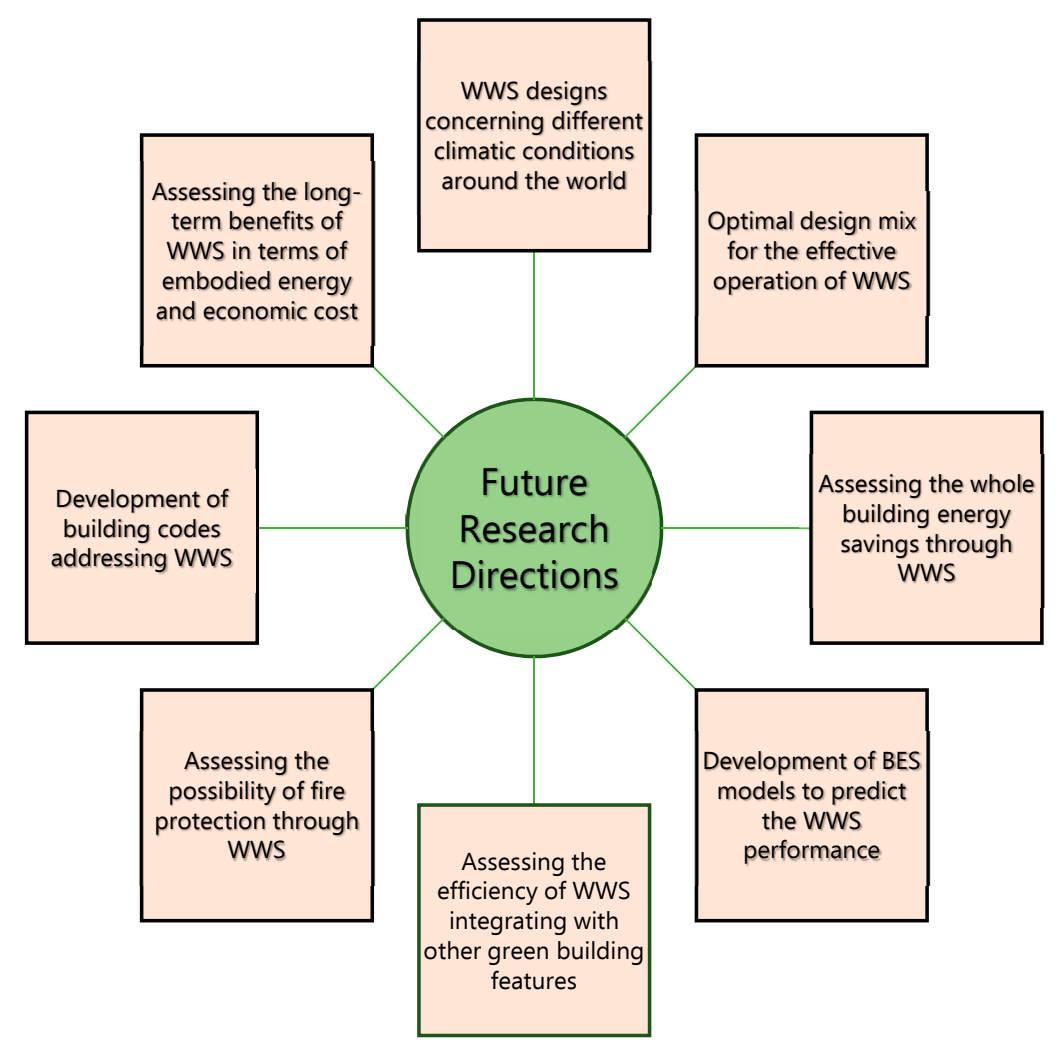

Figure 12. A summary of future research directions on WWS.

\section{Conclusions}

This paper reviews the research on WWS to assess WWS for energy-saving and fire safety when incorporated into green building façades. From the analysis, it is established that WWS has a significant impact on controlling energy efficiency and fire safety in green buildings. Nevertheless, careful attention is required in designing the façade in green buildings to minimize the solar gain to the building, allow sufficient daylight, and reduce the fire risk, so as to fully utilize the advantages of WWS. It is expected that water wall systems can provide an integrated solution for energy efficiency and fire safety of buildings attached with a water wall system as the façade. It is envisaged that this approach has a high potential to be applied in practice.

The possible energy efficiency of water wall systems has been studied comprehensively through different methods such as analytical modeling, experimental modeling, and numerical modeling (CFD). The studies suggest that the WWS are capable of reducing the temperature fluctuation, which can result in reduced energy cost when they are attached to the building façade. This system is economical and comes with a lot of green benefits. 
Moreover, prospective studies must tackle various challenges by systemic examination. The identified research gaps and challenges demand a comprehensive analysis in the future. Future research should focus on assessing the WWS performance for different climatic conditions, find the optimal design mix, assess the performance of WWS when incorporated into other green building features, development of BES programs addressing the simulation of WWS, assessing the fire performance of WWS, WWS life cycle appraisal of embodied energy and economic cost, and development of performance-based building codes addressing the WWS. With the results of these researches, efficient design of WWS with numerous social, environmental, and economic advantages makes the application of WWS in green buildings more appealing.

Author Contributions: Conceptualization, D.L. and C.L.C.; Writing original draft preparation, U.R.; Writing review and editing, D.L. and C.L.C., Supervision, C.L.C.; Funding acquisition, C.L.C. All authors have read and agreed to the published version of the manuscript.

Funding: This research was funded by a grant from the Research Grants Council of the Hong Kong Special Administrative Region, China (Project No. CityU 11211918).

Conflicts of Interest: The authors declare no conflict of interest.

\section{References}

1. Pérez, G.; Coma, J.; Sol, S.; Cabeza, L.F. Green facade for energy savings in buildings: The influence of leaf area index and facade orientation on the shadow effect. Appl. Energy 2017, 187, 424-437. [CrossRef]

2. Tzempelikos, A.; Athienitis, A.K.; Karava, P. Simulation of façade and envelope design options for a new institutional building. Sol. Energy 2007, 81, 1088-1103. [CrossRef]

3. Chen, J.; Qiu, Q.; Han, Y.; Lau, D. Piezoelectric materials for sustainable building structures: Fundamentals and applications. Renew. Sustain. Energy Rev. 2019, 101, 14-25. [CrossRef]

4. Chew, M.Y.L.; Conejos, S.; Azril, F.H. Bin Design for maintainability of high-rise vertical green facades. Build. Res. Inf. 2019, 47, 453-467. [CrossRef]

5. Aksamija, A. High-Performance Building Envelopes: Design Methods for Energy Efficient Facades. In Proceedings of the BEST4 Conference, Kansas City, MO, USA, 13-15 April 2015.

6. Haggag, M.; Hassan, A.; Elmasry, S. Experimental study on reduced heat gain through green façades in a high heat load climate. Energy Build. 2014, 82, 668-674. [CrossRef]

7. Khanna, T.; Chhugani, R. Intelligent Facades to Improve Sustainability E Comfort; NürnbergMesse India Pvt. Ltd.: New Delhi, India, 2016.

8. Wang, Y.; Fukuda, H. The influence of insulation styles on the building energy consumption and indoor thermal comfort of multi-family residences. Sustainability 2019, 11, 266. [CrossRef]

9. Rakhshandehroo, M.; Yusof, M.J.M.; Najd, M.D. Green Façade (Vertical Greening): Benefits and Threats. Appl. Mech. Mater. 2015, 747, 12-15. [CrossRef]

10. Carletti, C.; Sciurpi, F.; Pierangioli, L. The energy upgrading of existing buildings: Window and shading device typologies for energy efficiency refurbishment. Sustainability 2014, 6, 5354-5377. [CrossRef]

11. Khasreen, M.M.; Banfill, P.F.G.; Menzies, G.F. Life-cycle assessment and the environmental impact of buildings: A review. Sustainability 2009, 1, 674-701. [CrossRef]

12. Joseph, P.; Tretsiakova-McNally, S. Sustainable non-metallic building materials. Sustainability 2010, 2, 400-427. [CrossRef]

13. Guo, P.; Meng, W.; Nassif, H.; Gou, H.; Bao, Y. New perspectives on recycling waste glass in manufacturing concrete for sustainable civil infrastructure. Constr. Build. Mater. 2020, 257. [CrossRef]

14. Bahadori-Jahromi, A.; Rotimi, A.; Mylona, A.; Godfrey, P.; Cook, D. Impact of window films on the overall energy consumption of existing UK hotel buildings. Sustainability 2017, 9, 731. [CrossRef]

15. Zhou, A.; Wong, K.W.; Lau, D. Thermal insulating concrete wall panel design for sustainable built environment. Sci. World J. 2014, 2014. [CrossRef] [PubMed]

16. Zhou, A.; Yu, Z.; Chow, C.L.; Lau, D. Enhanced solar spectral reflectance of thermal coatings through inorganic additives. Energy Build. 2017, 138, 641-647. [CrossRef] 
17. Morakinyo, T.E.; Dahanayake, K.W.D.K.C.; Ng, E.; Chow, C.L. Temperature and cooling demand reduction by green-roof types in different climates and urban densities: A co-simulation parametric study. Energy Build. 2017, 145, 226-237. [CrossRef]

18. Wang, F.; Yang, W.J.; Sun, W.F. Heat transfer and energy consumption of passive house in a severely cold area: Simulation analyses. Energies 2020, 13, 626. [CrossRef]

19. Dahanayake, K.W.D.K.C.; Chow, C.L. Studying the potential of energy saving through vertical greenery systems: Using EnergyPlus simulation program. Energy Build. 2017, 138, 47-59. [CrossRef]

20. Chow, W.K.; Kong, H.; Gao, Y.; Dong, H.; Zou, G.W.; Han, S.S.; Kong, H.; Chow, C.L.; Kong, H. Experimental studies on fire response of glass façade systems. IJEPBFC 2006, 8, 54-68.

21. Khalaf, M.; Ashrafian, T.; Demirci, C. Energy Efficiency Evaluation of Different Glazing and Shading Systems in a School Building. E3S Web Conf. 2019, 111. [CrossRef]

22. Huang, Y.; Niu, J.L. Energy and visual performance of the silica aerogel glazing system in commercial buildings of Hong Kong. Constr. Build. Mater. 2015, 94, 57-72. [CrossRef]

23. Wang, Y.; Wu, Y.; Wang, Q.; Liew, K.M.; Chen, H.; Sun, J.; He, L. Numerical study on fire response of glass facades in different installation forms. Constr. Build. Mater. 2014, 61, 172-180. [CrossRef]

24. Stewart, M.G.; Netherton, M.D. Security risks and probabilistic risk assessment of glazing subject to explosive blast loading. Reliab. Eng. Syst. Saf. 2008, 93, 627-638. [CrossRef]

25. Vedrtnam, A.; Bedon, C.; Youssef, M.A.; Wamiq, M.; Sabsabi, A.; Chaturvedi, S. Experimental and numerical structural assessment of transparent and tinted glass during fire exposure. Constr. Build. Mater. 2020, 250. [CrossRef]

26. Bedon, C.; Zhang, X.; Santos, F.; Honfi, D.; Kozłowski, M.; Arrigoni, M.; Figuli, L.; Lange, D. Performance of structural glass facades under extreme loads-Design methods, existing research, current issues and trends. Constr. Build. Mater. 2018, 163, 921-937. [CrossRef]

27. Debuyser, M.; Sjöström, J.; Lange, D.; Honfi, D.; Sonck, D.; Belis, J. Behaviour of monolithic and laminated glass exposed to radiant heating. Constr. Build. Mater. 2017, 130, 212-229. [CrossRef]

28. Wang, Y.; Xie, Q.; Zhang, Y.; Wang, Q.; Sun, J. Sensitivity analysis of influencing factors on glass façade breakage in fire. Fire Saf. J. 2018, 98, 38-47. [CrossRef]

29. Cuzzillo, B.R.; Pagni, P.J. Thermal breakage of Double-Pane Glazing by Fire. J. Fire Prot. Eng. 1998, 9, 1-11. [CrossRef]

30. Wang, Y.; Wang, Q.; Sun, J.; He, L.; Liew, K.M. Influence of fire location on the thermal performance of glass façades. Appl. Therm. Eng. 2016, 106, 438-442. [CrossRef]

31. Pagni, P.J. Thermal glass breakage. Fire Saf. Sci. 2003, 3-22. [CrossRef]

32. Cho, S.H.; Chae, C.U. A study on life cycle CO2 emissions of low-carbon building in South Korea. Sustainability 2016, 8, 579. [CrossRef]

33. Tidwell, J. Bridging the Gap-Fire Safety and Green Buildings; National Association of State Fire Marshals: Burns, OR, USA, 2010.

34. Nayak, J.K. Thermal performance of a water wall. Build. Environ. 1987, 22, 83-90. [CrossRef]

35. Wu, T.; Lei, C. A review of research and development on water wall for building applications. Energy Build. 2016, 112, 198-208. [CrossRef]

36. Wu, T.; Lei, C. Thermal modelling and experimental validation of a semi-transparent water wall system for Sydney climate. Sol. Energy 2016, 136, 533-546. [CrossRef]

37. Wu, T.; Lei, C. CFD simulation of the thermal performance of an opaque water wall system for Australian climate. Sol. Energy 2016, 133, 141-154. [CrossRef]

38. Wang, H.; Lei, C. Theoretical modeling of combined solar chimney and water wall for buildings. Energy Build. 2019, 187, 186-200. [CrossRef]

39. Wang, H.; Lei, C. Combined Solar Chimney and Water Wall for Ventilation and Thermal Comfort. In Proceedings of the 4th International Conference on Building Energy, Environment, Melbourne, Australia, 5-9 February 2018; pp. 705-710.

40. Karabay, H.; Arici, M.; Sandik, M. A numerical investigation of fluid flow and heat transfer inside a room for floor heating and wall heating systems. Energy Build. 2013, 67, 471-478. [CrossRef]

41. Moustafa, M.A.; Aripin, S. CFD Evaluation of the pottery water wall in a hot adrid climate of Luxor, Egypt. J. Green Build. 2015. [CrossRef] 
42. Xiangfeng, L.; Tianxing, S. Conceptual Development of Transparent Water Storage Envelopes. Archit. Sci. Rev. 2007, 50, 18-25. [CrossRef]

43. Liu, X.; Guo, J.; Wang, J. Numerical and experimental studies on the energy performance of thermal mass windows. J. Build. Phys. 2018, 42, 692-721. [CrossRef]

44. Wang, X.; Kim, R.E.; Kwon, O.S.; Yeo, I. Hybrid Simulation Method for a Structure Subjected to Fire and Its Application to a Steel Frame. J. Struct. Eng. 2018, 144, 1-11. [CrossRef]

45. Kuznik, F.; David, D.; Johannes, K.; Roux, J.J. A review on phase change materials integrated in building walls. Renew. Sustain. Energy Rev. 2011, 15, 379-391. [CrossRef]

46. Tamme, R.; Laing, D.; Steinmann, W.D.; Bauer, T. Thermal Energy Storage. Sol. Energy 2013, 688-714. [CrossRef]

47. Perlin, J. Let It Shine: The 6,000-Year Story of Solar Energy; New World Library: Novato, CA, USA, 2013; ISBN 9781608681327.

48. Bainbridge, D.A. A Water Wall Solar Design Manual; San Diego, CA, USA, 2005; Available online: https: //www.solaripedia.com/files/472.pdf (accessed on 13 October 2020).

49. Maloney, T.J.; Habib, V. Design, Fabrication and Testing of a Marketable Waterwall Component; One Design, Inc.: Winchester, VA, USA, 1979; Volume 84.

50. Bainbridge, B.D.A.; Haggard, K.; Cooper, P. Return of the Water Wall. Sol. Today 2007, 38-41.

51. Saadatian, O.; Sopian, K.; Lim, C.H.; Asim, N.; Sulaiman, M.Y. Trombe walls: A review of opportunities and challenges in research and development. Renew. Sustain. Energy Rev. 2012, 16, 6340-6351. [CrossRef]

52. Saadatian, O.; Sopian, K.; Salleh, E.; Lim, C.H.; Riffat, S.; Saadatian, E.; Toudeshki, A.; Sulaiman, M.Y. A review of energy aspects of green roofs. Renew. Sustain. Energy Rev. 2013, 23, 155-168. [CrossRef]

53. Bevilacqua, P.; Benevento, F.; Bruno, R.; Arcuri, N. Are Trombe walls suitable passive systems for the reduction of the yearly building energy requirements? Energy 2019, 185, 554-566. [CrossRef]

54. Agrawal, B.; Tiwari, G.N. Building Integrated Photovoltaic Thermal Systems: For Sustainable Development; Royal Society of Chemistry: London, UK, 2011; ISBN 9781849732000.

55. Al-Karaghouli, A.; Kazmerski, L.L. Renewable Energy Opportunities in Water Desalination. Desalin. Trends Technol. 2011. [CrossRef]

56. McLaggan, M.S.; Hadden, R.M.; Gillie, M. Fire Performance of Phase Change Material Enhanced Plasterboard. Fire Technol. 2018, 54, 117-134. [CrossRef]

57. Khan, R.J.; Bhuiyan, M.Z.H.; Ahmed, D.H. Investigation of heat transfer of a building wall in the presence of phase change material (PCM). Energy Built Environ. 2020, 1, 199-206. [CrossRef]

58. Richman, R.C.; Cianfrone, C.; Pressnail, K.D. More sustainable masonry façades: Preheating ventilation air using a dynamic buffer zone. J. Build. Phys. 2010, 34, 27-41. [CrossRef]

59. Stazi, F.; Mastrucci, A.; Munafò, P. Life cycle assessment approach for the optimization of sustainable building envelopes: An application on solar wall systems. Build. Environ. 2012, 58, 278-288. [CrossRef]

60. Kisilewicz, T. On the role of external walls in the reduction of energy demand and the mitigation of human thermal discomfort. Sustainability 2019, 11, 61. [CrossRef]

61. Yang, L.; Yan, H.; Lam, J.C. Thermal comfort and building energy consumption implications -A review. Appl. Energy 2014, 115, 164-173. [CrossRef]

62. Li, D.; Wu, Y.; Wang, B.; Liu, C.; Arıc1, M. Optical and thermal performance of glazing units containing PCM in buildings: A review. Constr. Build. Mater. 2020, 233, 117327. [CrossRef]

63. Balcomb, J.D.; Mcfarland, R.D. A simple empirical method for estimating the performance of a passive solar heated building of the thermal storage wall type. In Proceedings of the 2nd National Passive Solar, University of Pennsylvania, Philadelphia, PA, USA, 16-18 March 1978.

64. Nayak, J.K.; Bansal, N.K.; Sodha, M.S. Analysis of passive heating concepts. Sol. Energy 1983, 30, 51-69. [CrossRef]

65. Sutton, R.G.; McGregor, R.J. Solarwall project: Two demonstration houses with passive solar heating in Tasmania. Archit. Sci. Rev. 1986, 29, 2-11. [CrossRef]

66. Turner, R.H.; Liu, G.; Cengel, Y.A.; Harris, C.P. Thermal Storage in the Walls of a Solar House. J. Sol. Eng. 1994, 116, 183-193. [CrossRef]

67. Yadav, Y.P.; Tiwari, G.N. Analytical model of a solarium for cold climate-A new approach. Energy Convers. Manag. 1988, 28, 15-20. [CrossRef] 
68. Din, M.; Tiwari, G.N.; Ghosal, M.K.; Srivastava, N.S.L.; Khan, M.I.; Sodha, M.S. Effect of thermal storage on the performance of greenhouse. Int. J. Energy Res. 2003, 27, 79-92. [CrossRef]

69. Tiwari, G.N.; Singh, A.K. Comparative Studies of Different Heating Techniques of a Non-air Conditioned Building. Build. Environ. 1996, 31, 215-224. [CrossRef]

70. Fuchs, R.; McClelland, J.F. Passive solar heating of buildings using a transwall structure. Sol. Energy 1979, 23, 123-128. [CrossRef]

71. Bansal, N.K.; Sodha, M.S.; Ram, S.; Singh, S.P. Evaluation of complex heat transfer coefficients for passive heating concepts. Build. Environ. 1987, 22, 259-268. [CrossRef]

72. Bansal, N.K.; Thomas, P.C. A Simple Procedure for Selection and Sizing of Indirect Passive Solar Heating Systems. Build. Environ. 1991, 26, 381-387. [CrossRef]

73. Bhandari, M.S.; Bansal, N.K. Solar heat gain factors and heat loss coefficients for passive heating concepts. Sol. Energy 1994, 53, 199-208. [CrossRef]

74. Nisbet, S.K.; Mthembu, N.S. Transwall modelling using effective conductivities. Sol. Energy 1992, 49, 127-138. [CrossRef]

75. Yadav, Y.P.; Tiwari, G.N. Large scale solar water heater: Experimental and theoretical studies. Energy Convers. Manag. 1991, 31, 337-351. [CrossRef]

76. Tiwari, G.N.; Kumar, S. Thermal evaluation of solarium-cum-passive solar house. Energy Convers. Manag. 1991, 32, 303-310. [CrossRef]

77. Upadhya, M.; Tiwari, G.N.; Rai, S.N. Optimum distribution of water-wall thickness in a transwall. Energy Build. 1991, 17, 97-102. [CrossRef]

78. Wang, W.L.; Tian, Z.; Niu, X.L.; Xu, X. Investigation on a Passive Solar House Equipped with Water Thermal Storage Wall. Appl. Mech. Mater. 2012, 178-181, 193-196. [CrossRef]

79. Sánchez-Ostiz, A.; Monge-Barrio, A.; Domingo-Irigoyen, S.; González-Martínez, P. Design and experimental study of an industrialized sunspace with solar heat storage. Energy Build. 2014, 80, 231-246. [CrossRef]

80. Sameti, M. A new design of a solar water storage wall: A system-level model and simulation. Energy Syst. 2018, 9, 361-383. [CrossRef]

81. Chow, T.T.; Li, C.; Lin, Z. Thermal characteristics of water-flow double-pane window. Int. J. Therm. Sci. 2011, 50, 140-148. [CrossRef]

82. Sodha, M.S.; Kaushik, S.C.; Nayak, J.K. Performance of trombe walls and roof pond systems. Appl. Energy 1981, 8, 175-191. [CrossRef]

83. Yadav, Y.P.; Tiwari, G.N. Transient analysis of a winter greenhouse integrated with solar still. Energy Convers. Manag. 1987, 27, 267-273. [CrossRef]

84. Tiwari, G.N.; Yadav, Y.P.; Lawrence, S.A. Performance of a solarium: An analytical study. Build. Environ. 1988, 23, 145-151. [CrossRef]

85. Xiangfeng, L.; Tianxing, S. The Development of Transparent Water Storage Envelopes (TWSE) through Theoretical Thermal and Optical Analyses. Archit. Sci. Rev. 2008, 51, 109-123. [CrossRef]

86. Chow, T.T.; Li, C. Water-filled double reflective window and its year-round performance. Procedia Environ. Sci. 2011, 11, 1039-1047. [CrossRef]

87. Lyu, Y.L.; Chow, T.T.; Wang, J.L. Numerical prediction of thermal performance of liquid-flow window in different climates with anti-freeze. Energy 2018, 157, 412-423. [CrossRef]

88. Gil-Lopez, T.; Gimenez-Molina, C. Influence of double glazing with a circulating water chamber on the thermal energy savings in buildings. Energy Build. 2013, 56, 56-65. [CrossRef]

89. Lyu, Y.L.; Chow, T.T. Evaluation of influence of header design on water flow characteristics in window cavity with CFD. Energy Procedia 2015, 78, 97-102. [CrossRef]

90. Chow, T.T.; Lyu, Y. Effect of design configurations on water flow window performance. Sol. Energy 2017, 155, 354-362. [CrossRef]

91. Liu, X.; Xu, M.; Guo, J.; Zhu, R. Numerical study on the energy performance of building zones with transparent water storage envelopes. Sol. Energy 2019, 180, 690-706. [CrossRef]

92. Gutai, M.; Kheybari, A.G. Energy consumption of water-filled glass (WFG) hybrid building envelope. Energy Build. 2020, 218, 110050. [CrossRef]

93. Sędłak, B.; Kinowski, J.; Sulik, P.; Kimbar, G. The risks associated with falling parts of glazed facades in case of fire. Open Eng. 2018, 8, 147-155. [CrossRef] 
94. Hasheminasab, H.; Zolfani, S.H.; Bitarafan, M.; Chatterjee, P.; Ezabadi, A.A. The Role of Façade Materials in Blast-Resistant Buildings: An Evaluation Based on Fuzzy Delphi and Fuzzy EDAS. Algorithms 2019, 12, 119. [CrossRef]

95. Nguyen, K.; Weerasinghe, P.; Mendis, P.; Ngo, T.; Barnett, J. Performance of modern building facades in fire: A comprehensive review. Electron. J. Struct. Eng. 2016, 16, 69-86.

96. McKenna, S.T.; Jones, N.; Peck, G.; Dickens, K.; Pawelec, W.; Oradei, S.; Harris, S.; Stec, A.A.; Hull, T.R. Fire behaviour of modern façade materials - Understanding the Grenfell Tower fire. J. Hazard. Mater. 2019, 368, 115-123. [CrossRef]

97. Wang, Y.; Zhang, Y.; Wang, Q.; Yang, Y.; Sun, J. The effect of glass panel dimension on the fire response of glass façades. Constr. Build. Mater. 2018, 181, 588-597. [CrossRef]

98. Chow, W.K.; Hung, W.Y.; Gao, Y.; Zou, G.; Dong, H. Experimental study on smoke movement leading to glass damages in double-skinned façade. Constr. Build. Mater. 2007, 21, 556-566. [CrossRef]

99. Quinn, M.; Nadjai, A.; Ali, F.; Abu-Tair, A. Experimental and numerical investigation of localised fire on glazing facades having different orientations. J. Struct. Fire Eng. 2013, 4, 153-164. [CrossRef]

100. Babrauskas, V. Glass breakage in fires. Fire Sci. Technol. Inc. 2011, 6-11. Available online: http: //doctorfire.com/GlassBreak.pdf (accessed on 13 October 2020).

101. Keski-Rahkonen, O. Breaking of window glass close to fire. Fire Mater. 1988, 12, 61-69. [CrossRef]

102. Pagni, P.J.; Joshi, A.A. Glass breaking in fires. Fire Saf. Sci. Proc. Third Int. Symp. 2006, 791-802. [CrossRef]

103. Mowrer, F. Window Breakage Induced by Exterior Fires; National Institute of Standards and Technology: Gaithersburg, MD, USA, 1997.

104. Chow, C.L. Numerical studies on smoke spread in the cavity of a double-skin façade. J. Civ. Eng. Manag. 2016, 22, 470-479. [CrossRef]

105. Manzello, S.L.; Gann, R.G.; Kukuck, S.R.; Prasad, K.R.; Jones, W.W. An experimental determination of a real fire performance of a non-load bearing glass wall assembly. Fire Technol. 2007, 43, 77-89. [CrossRef]

106. Wang, X.; Tan, Q.; Wang, Z.; Kong, X.; Cong, H. Preliminary study on fire protection of window glass by water mist curtain. Int. J. Therm. Sci. 2018, 125, 44-51. [CrossRef]

107. Turco, M.; Lhotsky, P.; Hadjisophocleous, G. Investigation into the use of a water curtain over openings to prevent fire spread. MATEC Web Conf. 2016, 46. [CrossRef]

108. Tseng, C.C.; Viskanta, R. Absorptance and transmittance of water spray/mist curtains. Fire Saf. J. 2007, 42, 106-114. [CrossRef]

109. Abdoh, D.A.; Ademiloye, A.S.; Liew, K.M. A meshfree analysis of the thermal behaviors of hot surface glass pane subjects to down-flowing water film via smoothed particle hydrodynamics. Eng. Anal. Bound. Elem. 2020, 120, 195-210. [CrossRef]

110. Shao, G.; Wang, Q.; Zhao, H.; Wang, Y.; Chen, H.; Su, Y.; Sun, J.; He, L. Maximum temperature to withstand water film for tempered glass exposed to fire. Constr. Build. Mater. 2014, 57, 15-23. [CrossRef]

111. Braun, J.E. Load control using building thermal mass. J. Sol. Energy Eng. Trans. ASME 2003, 125, 292-301. [CrossRef]

112. Shi, Y.; Liu, X. Research on the Literature of Green Building Based on the Web of Science: A Scientometric Analysis in Citespace (2002-2018). Sustainability 2019, 11, 3716. [CrossRef]

113. Cakmakli, A.B. Environmental Analysis of Construction Materials. In Green Building Management and Smart Automation; Solanki, A., Nayyar, A., Eds.; IGI Global: Pennsylvania, PA, USA, 2019; pp. 90-110. [CrossRef]

114. Akadiri, P.O.; Chinyio, E.A.; Olomolaiye, P.O. Design of A Sustainable Building: A Conceptual Framework for Implementing Sustainability in the Building Sector. Buildings 2012, 2, 126-152. [CrossRef]

115. Biswas, W.K. Carbon footprint and embodied energy consumption assessment of building construction works in Western Australia. Int. J. Sustain. Built Environ. 2014, 3, 179-186. [CrossRef]

116. Baird, G.; Alcorn, A.; Haslam, P. The Energy Embodied in Building Materials-Updated New Zealand Coefficients and Their Significance. Trans. Inst. Prof. Eng. New Zeal. Civ. Eng. Sect. 1997, 24, 46-54.

117. Lawson, B. Building Materials, Energy and the Environment: Towards Ecologically Sustainable Development; Royal Australian Institute of Architects: Victoria, Australia, 1996; ISBN 9781863180283.

118. Straube, J. Can Highly Glazed Building Façades Be Green. Available online: https://www.buildingscience. com/documents/insights/bsi-006-can-fully-glazed-curtainwalls-be-green (accessed on 19 October 2020).

119. Bunjongjit, S.; Ngaopitakkul, A. Feasibility study and impact of daylight on illumination control for Energy-saving lighting systems. Sustainability 2018, 10, 4075. [CrossRef] 
120. Kaminska, A.; Ozadowicz, A. Lighting control including daylight and energy efficiency improvements analysis. Energies 2018, 11, 2166. [CrossRef]

121. Al-Mansour, A.; Chow, C.L.; Feo, L.; Penna, R.; Lau, D. Green concrete: By-products utilization and advanced approaches. Sustainability 2019, 11, 5145. [CrossRef]

122. Albayyaa, H.; Hagare, D.; Saha, S. Energy conservation in residential buildings by incorporating Passive Solar and Energy Efficiency Design Strategies and higher thermal mass. Energy Build. 2019, 182, 205-213. [CrossRef]

123. Aboulnaga, M.M. Towards green buildings: Glass as a building element-The use and misuse in the gulf region. Renew. Energy 2006, 31, 631-653. [CrossRef]

124. Altan, H.; Hajibandeh, M.; Aoul, T.K.A.; Deep, A. Passive design. In Springer Tracts in Civil Engineering; Springer: Cham, Switzerland, 2016; pp. 209-236. [CrossRef]

125. Burkett, K. The Hidden Architecture Behind 7 Deceiving Façades. Architizer, 2019. Available online: https://architizer.com/blog/inspiration/collections/deceiving-facades (accessed on 13 October 2020).

126. Nijsse, R.; Wenting, R. Designing and constructing corrugated glass facades. J. Facade Des. Eng. 2014, 2, 123-131. [CrossRef]

127. Allen, E. How Buildings Work; Oxford UniversityPress: New York, NY, USA, 2005; Volume 53, ISBN 9788578110796.

128. Maller, C.; Townsend, M.; Pryor, A.; Brown, P.; St Leger, L. Healthy nature healthy people: "contact with nature" as an upstream health promotion intervention for populations. Health Promot. Int. 2006, 21, 45-54. [CrossRef] [PubMed]

129. De Been, I.; Beijer, M. The influence of office type on satisfaction and perceived productivity support. J. Facil. Manag. 2014, 12, 142-157. [CrossRef]

130. Adams, S.; Becker, M.; Krauss, D.; Gilman, C. Not a Dry Subject: Optimizing Water Trombe Walls. Sol. Energy Soc. Annu. Conf. 2010, 2010, 1334-1340.

131. Tiwari, G.N.; Upadhya, M.; Rai, S.N. Relative thermal performances of south walls in winter. Energy Build. 1991, 17, 313-320. [CrossRef]

132. Crawley, D.B.; Hand, J.W.; Kummert, M.; Griffith, B.T. Contrasting the capabilities of building energy performance simulation programs. Build. Environ. 2008, 43, 661-673. [CrossRef]

Publisher's Note: MDPI stays neutral with regard to jurisdictional claims in published maps and institutional affiliations.

(C) 2020 by the authors. Licensee MDPI, Basel, Switzerland. This article is an open access article distributed under the terms and conditions of the Creative Commons Attribution (CC BY) license (http://creativecommons.org/licenses/by/4.0/). 